\title{
ANATOMY OF A DRESS: \\ Constructing a narrative within a museum setting
}

by Anya Georgijevic B.F.A., Alberta College of Art and Design, 2002

A Major Research Project presented to Ryerson University

in partial fulfillment of the

Requirements for the degree of

Masters of Arts

in the Program of

Fashion Studies

Toronto, Ontario, Canada, 2018

(c) Anya Georgijevic 2018 


\section{Author's Declaration}

\section{AUTHOR'S DECLARATION FOR ELECTRONIC SUBMISSION OF A MAJOR RESEARCH PROJECT (MRP)}

I hereby declare that I am the sole author of this MRP. This is a true copy of the MRP, including any required final revisions, as accepted by my examiners.

I authorize Ryerson University to lend this MRP to other institutions or individuals for the purpose of scholarly research.

I further authorize Ryerson University to reproduce this MRP by photocopying or by other means, in total or in part, at the request of other institutions or individuals for the purpose of scholarly research.

I understand that my MRP may be made electronically available to the public. 


\begin{abstract}
Anatomy of a Dress utilises object-based research to explore exhibition design and display. The goal of this project is to challenge the static nature of garment display in a museum or a gallery setting. This investigation materialises in the form of a small exhibition pavilion, using a 1950s ballgown by Julian Rose from the Ryerson Fashion Research Collection as its primary subject matter. The dress was analysed through a series of explorations, including technical drawings, x-rays, and 3D fabrication, all of which informed the design of the exhibition.
\end{abstract}




\section{Acknowledgements}

I would first like to thank my MRP supervisor Professor Lois Weinthal for the incredible support throughout this process. My design practice developed tremendously with her invaluable input and encouragement.

I would like to acknowledge my second reader Professor Alison Matthews David for always providing valuable advice and inspiration throughout the program.

This project would not have been possible without Ingrid Mida at the Ryerson Fashion Reseach Collection, where I spent many hours playing dress detective.

A special thank you to Naveed Khan and the staff at the FCAD Digital Fabrication Lab who spent countless hours helping me bring my miniature vision to life. And thank you to Adrian Kenny at the RSID Workshop for the table saw services.

I would also like to thank 3D artist Jenny Bermas for the crucial 3D modeling assistance. Without her, I would have spent days and days banging my head against the computer monitor.

I would love to acknowledge the loving and unconditional support of my family, without whom I would be lost in the world. And, finally, a very warm and special thanks to my dog Bun, who has not left my side in over nine years. 


\section{Table of Contents}

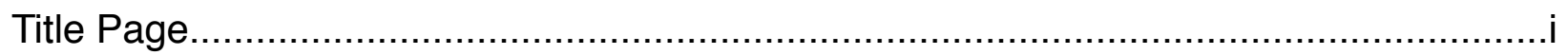

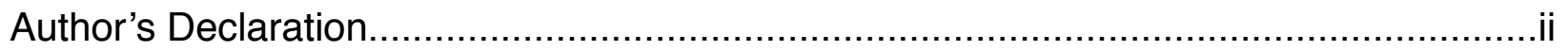

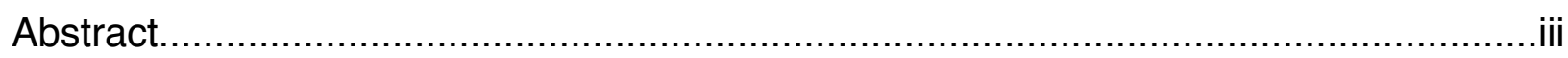

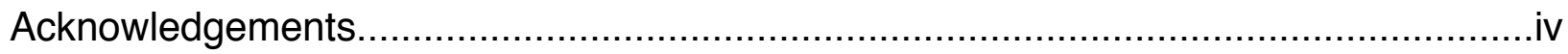

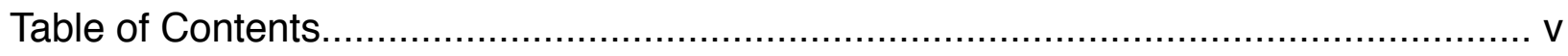

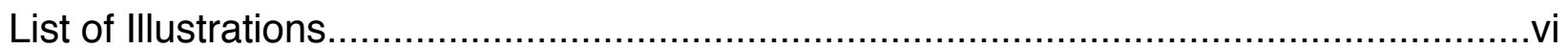

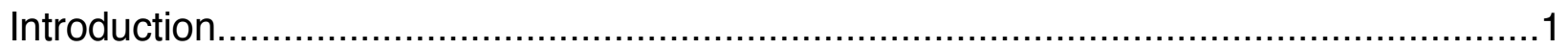

Chapter 1: Literature Review

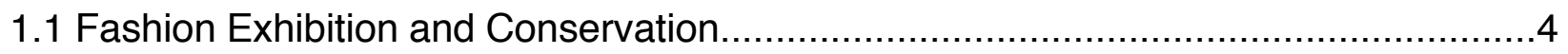

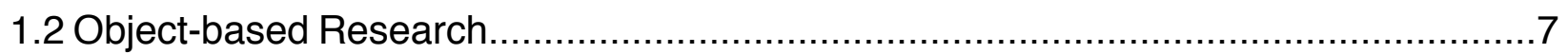

Chapter 2: Methodology

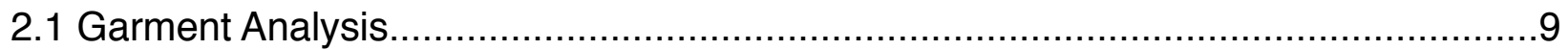

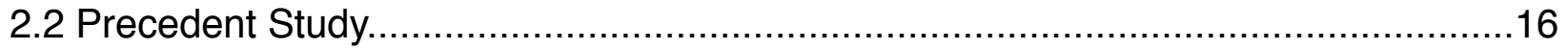

Chapter 3: Pavilion Design

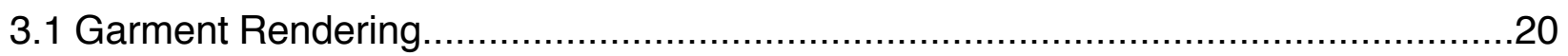

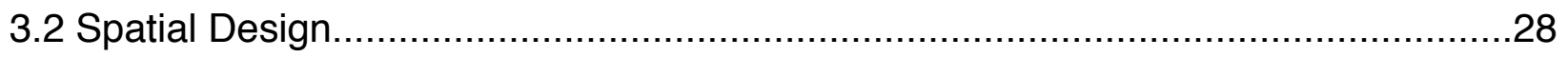

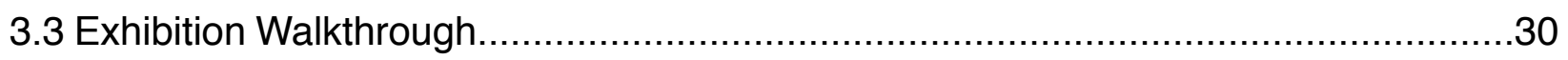

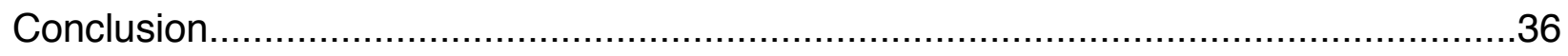

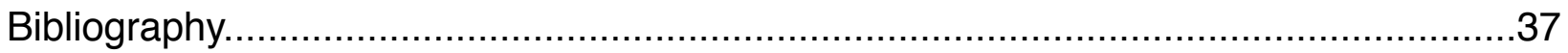




\section{List of Figures}

Figure

Page

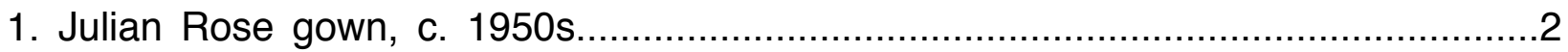

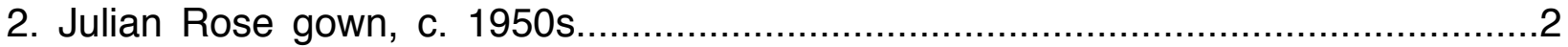

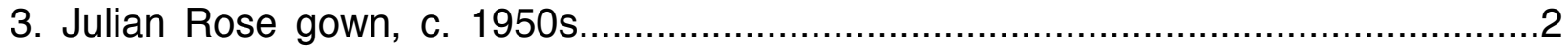

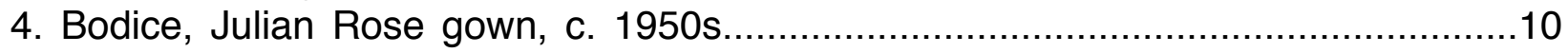

5. Hoop skirt interior, Julian Rose gown, c. 1950s............................................11

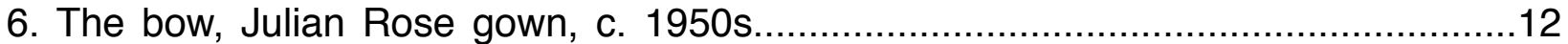

7. Julian Rose advertisement, British Vogue, November 1953................................13

8. Day dress, Christian Dior, Vogue, April 1947....................................................14

9. Evening dress, Jenny, Vogue, April 1920......................................................14

10. Evening dress, Norman Hartnell, Vogue, May 1939..........................................15

11. Charles James: Beyond Fashion, The Metropolitan Museum of Art........................16

12. Charles James: Beyond Fashion, The Metropolitan Museum of Art........................17

13. The Concise Dictionary of Dress, Victoria \& Albert Museum.................................18

14. The Concise Dictionary of Dress, Victoria \& Albert Museum ................................19

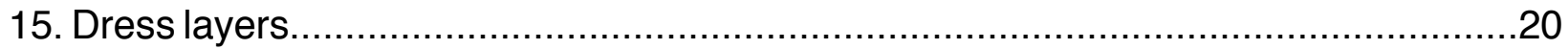

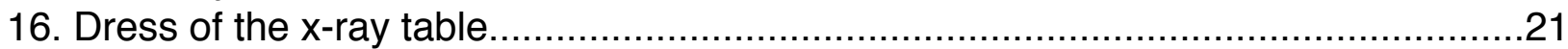

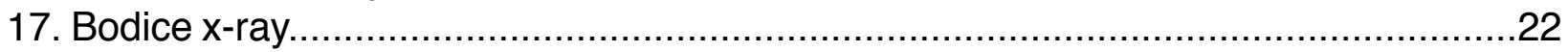

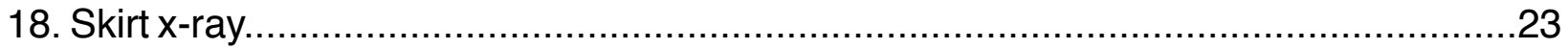

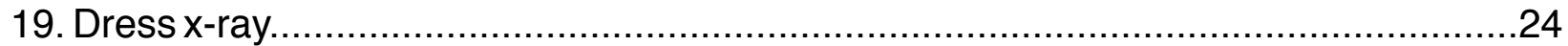

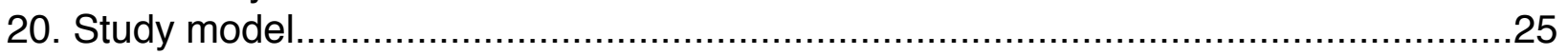

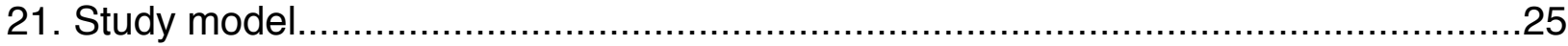

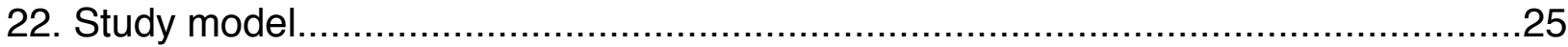

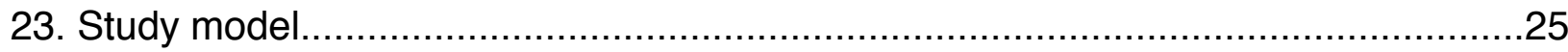

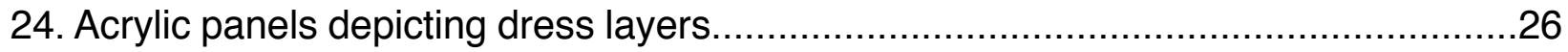

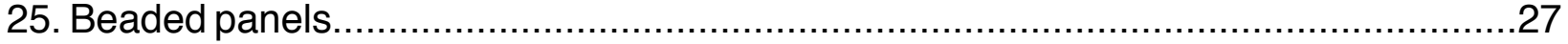

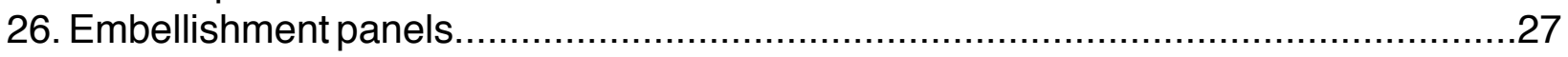

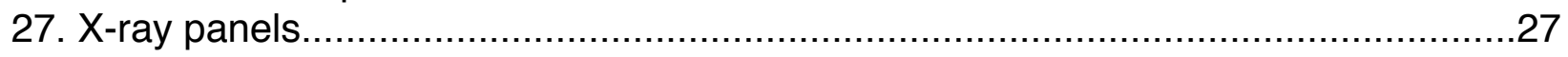

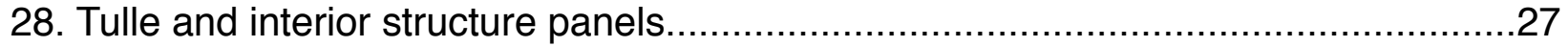

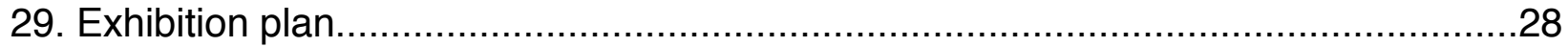

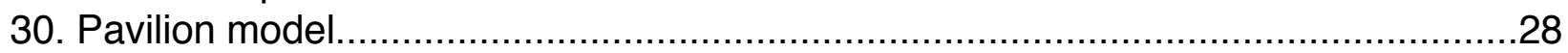

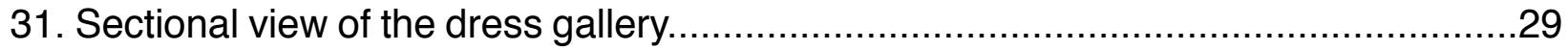

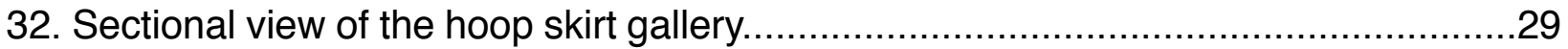

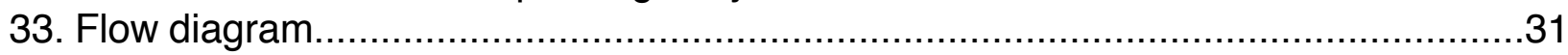

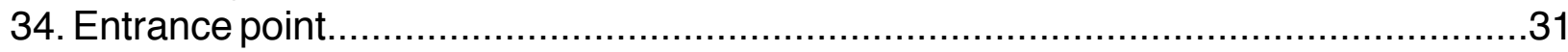

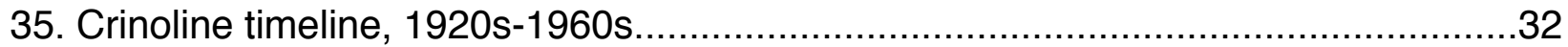

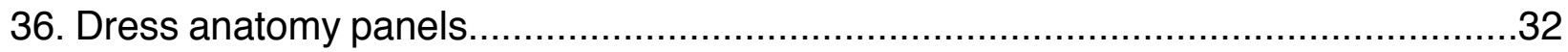

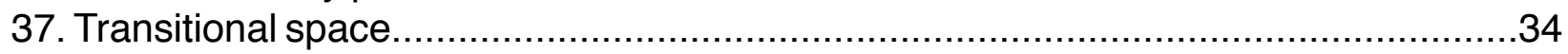

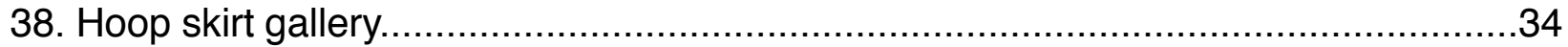

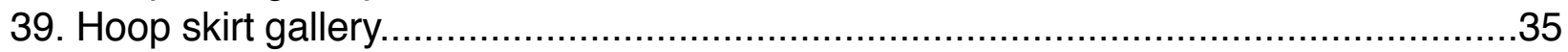

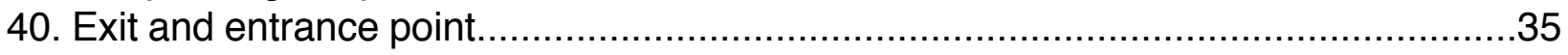




\section{Introduction}

Once a garment becomes a part of a museum collection, it will never again be worn by a human body. This matter of conservation can pose a challenge once a garment is displayed for public viewing. This Major Research Project (MRP) explores innovative approaches to garment display in a museum setting. Using object-based research, this creative project examines exhibition design and garment display. The small exhibition, in the form of a pavilion, focuses on one historical dress from the Ryerson Fashion Research Collection: a 1950s ballgown by London-based designer Julian Rose. The dress is analysed through a series of displays that showcase its materiality and place it within a larger historical context.

My intention is to investigate different ways a single garment can be presented in a museum environment. This exploration relies on the use of digital media and fabrication to deconstruct and reconstruct the dress in order to highlight its key narratives, and provide historical context. Through the use of $x$-rays and digital fabrication, the displays are designed to communicate the intricate construction of the garment. The project's aim is to challenge the static nature of garment display that is still predominant in museum exhibitions. The definition of static in this instance describes displays where a garment is placed on a stationary mannequin or a dress form and instances where it is laid flat in a glass box.

We experience fashion through movement and touch, neither of which are possible in a museum setting. Because museums adhere to strict codes of ethics and conservation, garments in their collections cannot be staged in the dynamic manner of a fashion runway presentation. While there have been instances where live models were used in a fashion exhibition context, the garments on display were works by contemporary designers who used pieces from their own archives for the occasion. According to Ingrid Mida in an article titled "Animating the Body in Museum Exhibitions of Fashion 
and Dress" (2015), live displays and exhibition catalogues featuring models in artifacts were more common before 1987 when the Costume Society of America resolved that a human body should not wear articles intended for preservation (p.44).

Objects in museum collections are often fragile due to their age, and therefore irreplaceable. In an article titled "Untouchable: Creating Desire and Knowledge in Museum Costume and Textile Exhibitions" (1998), Alexandra Palmer recognises the conundrum of presenting a still object that is meant to be experienced in movement: "They must remain static in order to meet conservation codes. Museums have to animate costume and textiles objects through other means" (p.34). This helped set up critical

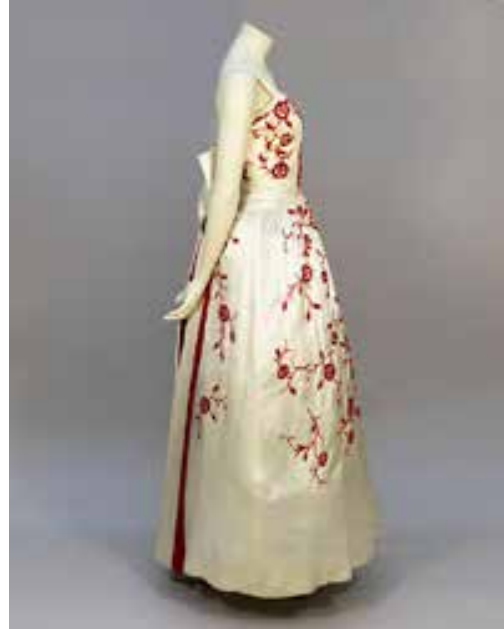

Figure 1: Ballgown (side view), Julian Rose, c. 1950s, Ryerson Fashion Collection

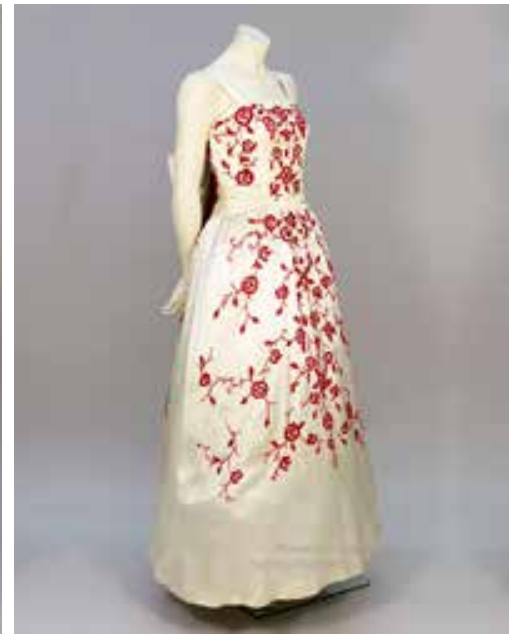

Figure 2: Ballgown (side view), Julian Figure 3: Ballgown (front view), Julian

Figure 2: Ballgown (side view), Julian Figure 3: Ballgown (front view), Julian Rose, c. 1950s, Ryerson Fashion Collection

questions for my research:

1) How can the garment's tailoring and construction be visually revealed without the ability to flip it inside out?;

2) How can we utilise new media technologies (3D printing and scanning, digital x-raying) to create innovative ways of garment presentation?;

3) How can the garment inspire the design of the space?

To explore these questions, I chose to work with a 1950s ball gown by Julian Rose

(Fig. 1-3) from the Ryerson Fashion Research Collection (Accession Number: 
FRC2014.07.517). Rose was a prominent London-based designer who was frequently featured in British Vogue throughout the 1950s and 1960s. With its hourglass silhouette that was popularised by Dior's New Look, the garment, which is described to be in "FairGood Condition," is an excellent representation of 1950s formal ready-to-wear womenswear tailoring. Its construction embodies the era's nostalgic return to the late-1800s silhouette of a nipped-in waist and full, voluminous skirt. This garment was chosen for its complex construction and layers that could inspire multiple forms of display.

Key Definitions: garment display, fashion exhibition, exhibition design, digital conservation, fashion history, object-based research 


\section{Chapter 1: Literature Review}

\subsection{Fashion Exhibition and Conservation}

The scholarship on exhibitions is considered to be somewhat of a new field in fashion studies. "Collecting dress artefacts to illustrate the history of Western dress is a relatively new aspect of museology." (Mida and Kim 18). Thus, my research was limited to only a few pioneering sources.

The Exhibiting Fashion: Before and After 1971 anthology is the most comprehensive book on the subject. Authors Judith Clark, Amy de La Haye and Jeffrey Horsley catalogued every major fashion exhibition since the 1930s, keeping the main focus on the seminal 1971 exhibition Fashion: An Anthology by Cecil Beaton that they consider as "a moment of shift in fashion curatorship" (6). The authors also discussed the role of an exhibition designer, a position that did not exist before World War II. They highlight the work of James Gardner for introducing theatrical display techniques to the fashion exhibition (33-37) that positioned the genre away from other museum exhibitions. Gardner's playful arrangements such as the shop windows in the Britain Can Make It (1946) exhibition helped set the tone for future fashion exhibitions.

Edited by Marie Riegels Melchior and Birgitta Svensson, Fashion and Museums: Theory and Practice (2014) provided a comprehensive survey of the history of dress exhibition and different approaches to display used by curators. In the introductory essay, Melchior explained why fashion exhibitions had become a recent phenomenon by discussing the Swedish ethnologist Orvar Löfgren's term "catwalk economy" (2). Löfgren suggested that the rise of public interest in consuming fashion has directly contributed to the demand for showcasing fashion (Melchior and Svensson 3). Although perhaps driven by the commercial economy, fashion in a museum context has to be understood as far more complex than a desirable commodity (Melchior and Svensson; Entwistle). According to Melchior and Svensson, the success of the fashion programming of the 
"mega-museums" such as The Metropolitan Museum (MMA) in New York and the Victoria \& Albert Museum $(V \& A)$ in London in the last quarter of the past century had attributed not only to the launches of many smaller specialized museums in recent years such as the Bata Shoe Museum in Toronto, but also inspired many fashion corporations to create personal museums such as the Gucci Museum in Florence to serve their own brand narratives.

In "Untouchable: Creating Desire and Knowledge in Museum Costume and Textile Exhibitions" (2008) Palmer argued that fashion brands tend to offer a more interactive, immersive experience because they don't have to adhere to codes of ethics and conservation (34). She used an example of a Waist Down: Skirts by Miuccia Prada store exhibition in which the skirts were "dramatically spinning on fans, placed on under-lit mannequins, and plastered on walls" (34). Palmer is quick to point out that while evocative, this type of dress animation would not be possible in a museum. She also questioned the curator's present position of having to compete with commercial displays, stating that the curator is in danger of becoming a "glorified stylist" (35). Much of this criticism comes from the 1972 appointment of former Vogue editor-in-chief Diana Vreeland as the special consultant at the MMA's Costume Institute.

Her tenure is also discussed by Harold Koda and Jessica Glasscock in "The Costume Institute at the Metropolitan Museum of Art: An Evolving History" (2014). Vreeland, who did not have a background in museum studies or academia, helped put together theatrical exhibitions worthy of Vogue editorials, often at the risk of compromising the conservation of the garments. In a scandalous move, the former editor placed opened bottles of Yves Saint Laurent's Opium perfume to set the right mood for the Manchu Dragon: Costumes in China exhibit (Palmer, "Museum Quality" 11). Although questionable because chemicals in the perfume can be damaging to artefacts, it could be argued that Vreeland's audacity succeeded in animating the exhibition beyond the visual. Her choices were not always made with academic criteria in mind, but Vreeland made a 
lasting impact on how fashion history is conveyed.

The MMA continued to push the boundaries of the display, combining cinematic strategies with academic thought. For Poiret: King of Fashion (2007), the Costume Institute's then curator Harold Koda commissioned animations showing Poiret's designs fold from a single piece of fabric into a garment. They were projected on the wall behind the corresponding dress form. For Alexander McQueen: Savage Beauty (2011), Andrew Bolton commissioned a fully immersive environment, complete with holograms, videos, rotating platforms, mirrors, and music. For Charles James: Beyond Fashion (2014), Koda enlisted architecture firm Diller Scofidio + Renfro to design X-ray scanning robots whose purpose was to live-scan the gowns, thus revealing their hidden complex structure. Because of the delicate state of some Charles James garments, replicas were commissioned for exhibition purposes. (This exhibition is described in more detail as a precedent study in Chapter 2.)

The ethics behind replication of artefacts are discussed in Refashioning and Redress: Conserving and Displaying Dress (2016), edited by Mary Brooks and Dinah Eastop. In an essay in this book titled "A Delicate Balance: Ethics and Aesthetics at the Costume Institute, Metropolitan Museum of Art, New York," Sarah Scaturro and Joyce Fung explained the decisions made regarding the Charles James exhibition and general "exhibitability" of garments (161). The MMA has a policy of not displaying damaged pieces, thus the curators and conservators came up with a solution to replace a flounce of one dress with a replica for the exhibition purposes.

In "Untouchable: Creating Desire and Knowledge in Museum Costume and Textile Exhibitions," Palmer also pondered the display of damaged garments, proposing that the tremendous work involved in the conservation of the garments should be put on display as well. "Highlighted would be the physical and scientific effects of time on fashion history, along with the new conservation record that has become a vital part of the garment's history" (Palmer 58). Palmer also criticised costume and textile exhibitions for 
not providing educational or intellectual perspective, but merely offering a visual experience, as if the garments can "speak for themselves" (56).

\subsection{Object-based Research}

"Because intellectuals live by the word, many scholars tend to ignore the important role that objects can play in the creation of knowledge" (Steele, "A Museum of Fashion" 327). According to Steele, object-based research provides valuable insights into the historic development of fashion, although historians seldom use it. Object-based research stems from anthropology and art history, both much older disciplines than fashion studies.

Many fashion historians have adopted methodologies developed by Jules Prown as outlined in his often cited 1982 article, "Mind in Matter: An Introduction to Material Culture Theory and Method." Prown argued that "artefacts are primary data for the study of material culture, and, therefore, they can be used actively as evidence rather than passively as illustrations" (Prown in Steele, "A Museum of Fashion" 329). He developed an object analysis methodology consisting of three phases: Description, documenting the internal evidence; Deduction, translating the relationship between the object and the perceiver; and Speculation, framing theories and hypotheses that might explain the various effects observed. (Prown 7-10).

For The Dress Detective: A Practical Guide to Object-based Research, Mida and Kim adapted this three-phase methodology into a new framework: Observation, capturing the information from the artefact; Reflection: contemplating embodied experience and contextual material; and Interpretation, linking the observations and reflections to theory (Mida and Kim 27). Based on Prown's, their framework is specifically applicable to dress research. Beneficial to my study is their "Slow Approach to Seeing," a method of careful looking in the Observation phase. This method encourages the researcher to take his or her time examining every inch of the garment so that no detail is missed. 
Adding to the importance of contextual and comparative material is Steele, who cited E. McClung Fleming's method of Evaluation in which "comparisons with other objects" is a crucial step in the study of artefacts. Steele also suggested using a theory of semiotics to look at the meaning of subtle detailing, such as floral appliqué or bows, on the garment (Steele, "A Museum of Fashion" 332). These meanings can significantly affect the interpretation of the garment.

All the information gathered from object-based research may or may not be communicated once the garment is displayed in a museum setting. "These objects, rescued from their certain deaths as commodities, are placed into a narrative within a museum, which produces new, historical meaning for them as embodied memories" (Petrov 226). It is a curator's decision to present the most relevant knowledge in the context of that exhibition, as it may be impossible to convey every aspect of the artefact. 


\section{Chapter 2: Methodology}

\subsection{Garment Analysis}

The investigation began with a material culture analysis of the Julian Rose gown from the Ryerson Fashion Research Collection (Accession Number: FRC2014.07.517). I had chosen the gown for its disguised complex construction and strong visual impact. I used the three-step methodology-observation, reflection, and interpretation-outlined by Mida and Kim in The Dress Detective: A Practical Guide to Object-based Research in Fashion (27), which is grounded in object-based research methods of Jules Prown.

\section{Observation}

During my first visit to the Ryerson Fashion Research Collection, I used Mida and Kim's Checklist for Observation as a guide for my analysis. At first glance, this was a classic example of a formal 1950s gown. The floor-length gown was made from cream-coloured silk satin, fabric and colour associated with weddings or debutante balls. The condition of the dress was good, with its seams intact, although the satin was showing visible yellowing and possible water damage. The dress showed evidence of alteration and repair, suggesting that it was worn more than once. The label inside the back of the dress reads, "Julian Rose London."

The floor-length dress has a bodice of a cream fabric that is machine embroidered with red roses, with a sweetheart neckline held by two straps (Fig.4 - insert bodice view). The bodice is supported by nine spiral bones sewn into the garment. The bust line is padded to achieve a voluptuous look. The bodice has satin straps and pleated waistband that connects to the large ivory and red satin bow at the back of the dress. The waistline measures 26 inches $(66 \mathrm{~cm})$. The front of the bodice is made with three pieces of fabric, while the back is made out of two. Side seams join the front and back. There are darts in the bust line, but no additional shaping in the back. The bust of the 
dress measures 14 inches $(35.56 \mathrm{~cm})$ across. The back of the bodice features a zipper that acts as a singular dress enclosure. The bodice features two ruched waist bands, joined together in the rear by three hook and eye clasps. The left side of the back of the bodice has an attached red and cream satin bow, which runs the entire length of the gown. The bow is further connected with a snap button.

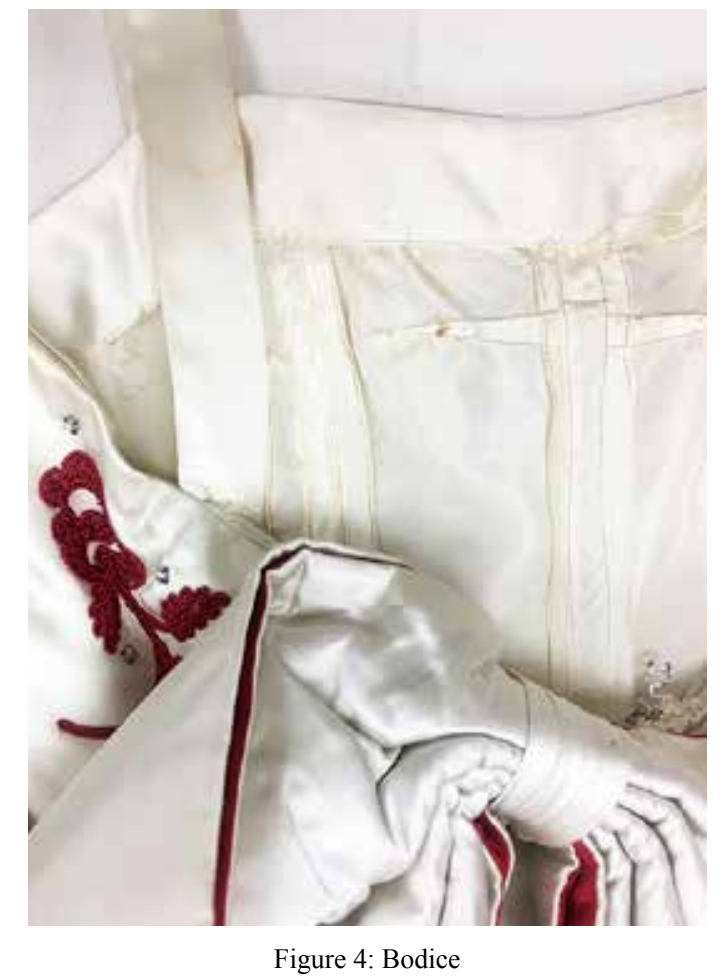

The floor-length cream satin skirt flares considerably from waist to hem and features the same red roses embroidery. The length of the skirt measures 38.5 inches $(95.25 \mathrm{~cm})$, suggesting that it was worn by a woman of average height. The skirt features an attached four-hooped crinoline (Fig. 5) and two layers of tulle with a peplum silhouette. The intricate construction is completely hidden under luxurious ivory peau de soie that is embellished with embroidered red cord floral vine motif and rhinestone studs. The dress is constructed with a mix of machine and hand-stitching. Most seams are machine-stitched, with hand-finishing of the hem of the skirt and the bow attachment. Both the bodice and the skirt have beadwork embellishment, in the form of small 
hand-sewn rhinestones that are scattered throughout the front and the back.

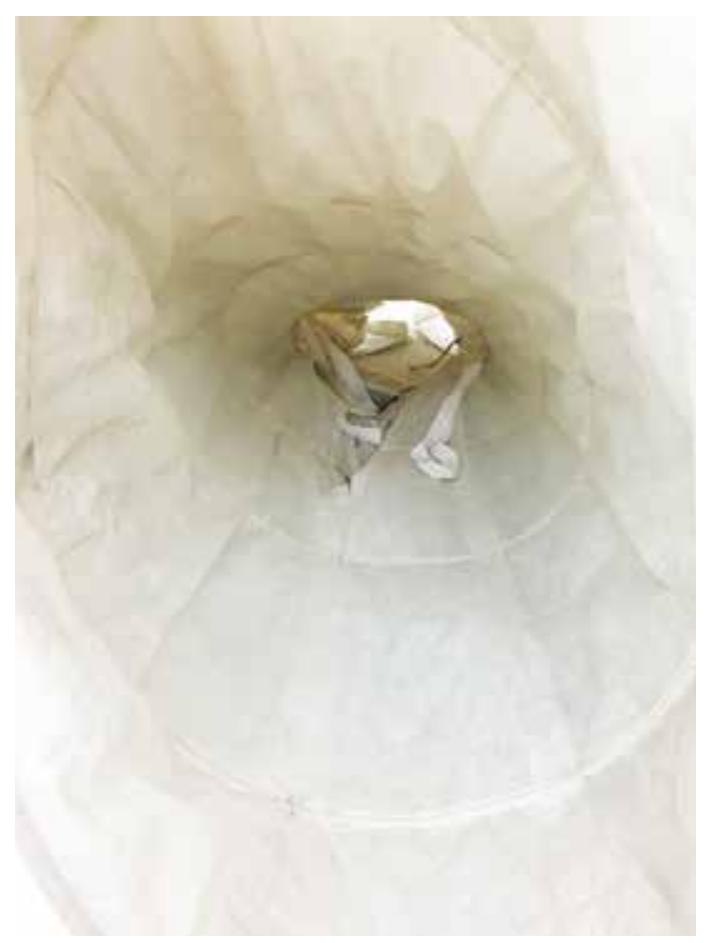

Figure 5: Hoop skirt interior

\section{Reflection}

The ballgown is elegant in its appearance, due to the high quality of the fabrics used and its intricate detailing. Since the garment was machine-stitched, it suggests that it was a ready-to-wear piece and there are most likely multiples. But its high-quality materials and high level of artistry place the garment in the luxury variety of the ready-towear category. The ivory satin and deep red rose embroidery give the gown a delicate, romantic feel, and suggest that it may have been worn for a highly elegant occasion, such as a formal ball or the opera.

One of the most noticeable elements is the oversized sculptural bow at the back (Fig. 6), which runs from the top of the bodice all the way to the floor. The bow was a common decorative element for formal dresses throughout the 1950s and 1960s, often seen in the designs of Hubert de Givenchy and Cristóbal Balenciaga. It gives the gown a sense of playfulness and youthful energy, contrasted against an arguably old-fashioned silhouette. It is easy to imagine this dress in motion when the crinoline skirt and 
the bow would sway gently during movement. When in motion, the heavy satin fabric would have held everything in place, protecting the illusion of effortless volume.

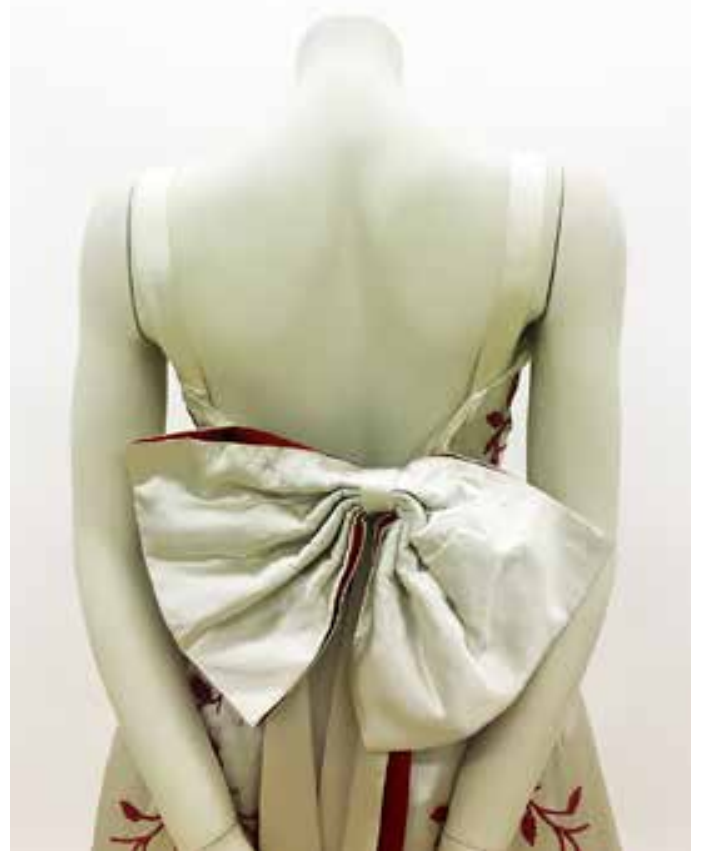

Figure 6: The bow

The Julian Rose gown came to the Ryerson Fashion Research Collection as part of a generous donation of artefacts from the Cleaver-Suddon Collection, originated by the late Alan Suddon (a fine arts librarian at the Toronto Reference Library), although its original owner is unknown. The dress was illustrated in In Style: 100 Years of Canadian Women's Fashion (1993) by Caroline Routh. The university collection has no provenance or photographs associated with this dress, and thus there is no information about the wearer or the occasions on which it was worn. A search through prominent museum collections - The Costume Institute at the MMA, The Museum at FIT, The Victoria \& Albert Museum, and Fashion Museum Bath-produced no results.

To find out more about the designer, I searched the British Vogue archives at the Toronto Reference Library and concluded that Julian Rose was an advertiser (Fig. 7) throughout the 1950s and the 1960s. He was a member of the Fashion House Group of London, which was formed in 1958 by a group of British designers who created collec- 
tions to be sold in high street stores (Come Step Back in Time). The group was also the organiser of London Fashion Week. Numerous Julian Rose advertisements from British Vogue lists his company address as 52 South Molton Street, London, which placed him in the heart of Mayfair district in central London, best known in fashion as the location of Savile Row. Aside from advertisements, Rose was prominently featured in fashion editorials, including the November 1956 cover. Well-known London-based model Barbara Goalen was the face of his collections.

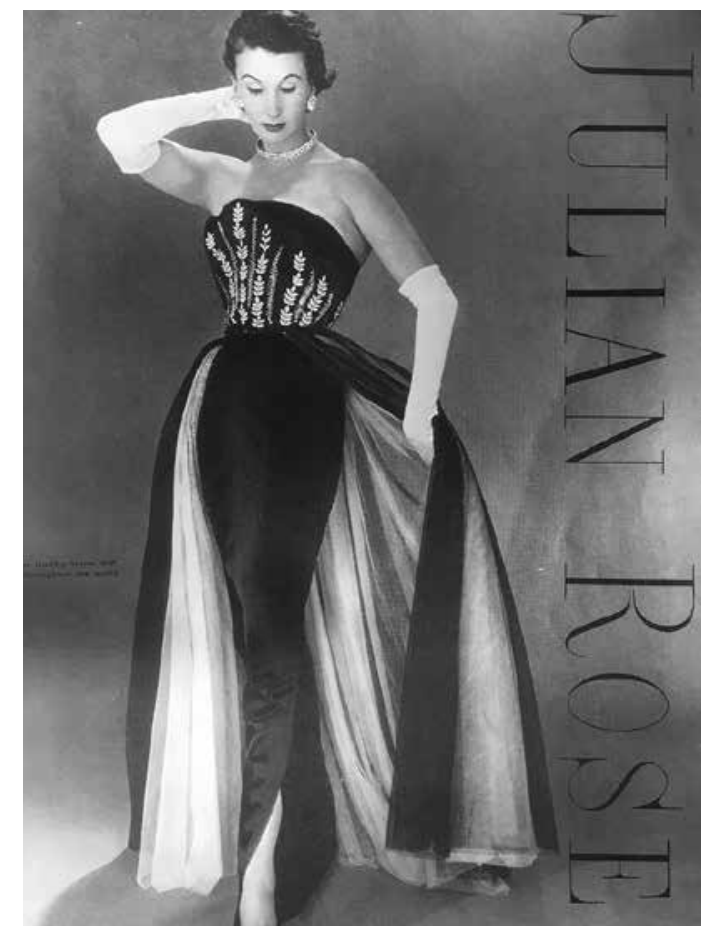

Figure 7: Julian Rose advertisement, British Vogue, November 1953

Although Julian Rose is not part of major museum collections, the dress, for its silhouette, can be compared to garments by the great couturiers of the era, such as Cristóbal Balenciaga, Pierre Balmain, Christian Dior, Hubert de Givenchy, and Charles James. Many of their garments would have featured similar, albeit much more intricate construction, with a boned bodice, hoop skirt, and layers of tulle. The Julian Rose gown is an admirable example of how haute couture construction and methods were translated to a ready-to-wear garment meant for mass production. 


\section{Interpretation}

This dress, with its exemplary 1950s eveningwear silhouette, represents a feminine ideal of the era. Fashion historians credit the shape to Christian Dior's New Look (Fig. 8), a 1947 collection that is widely considered to be a game-changer in womenswear, one that took a straight, sensible, wartime women's silhouette to complete opposite. "I designed clothes for flower-like women, with rounded shoulders, full, feminine busts, and hand-spun waists above enormous spreading skirts," said Christian Dior at the time (Black 159). While Dior's collection undoubtedly popularised the full skirt silhouette, the shape was slowly regaining popularity in eveningwear since 1920. A "crinoline" search through Vogue archives shows a short evening hoop-skirted Robe de Style dress by Paris-based couturier Jenny (Fig. 9) and a similar undergarment by Worth - both circa 1920. In the late 1930s, London-based couturier Norman Hartnell became a sensation for his ballgown designs (Fig. 10) for Queen Elizabeth (later known as the Queen Mother), which closely resembled Victorian era silhouettes.

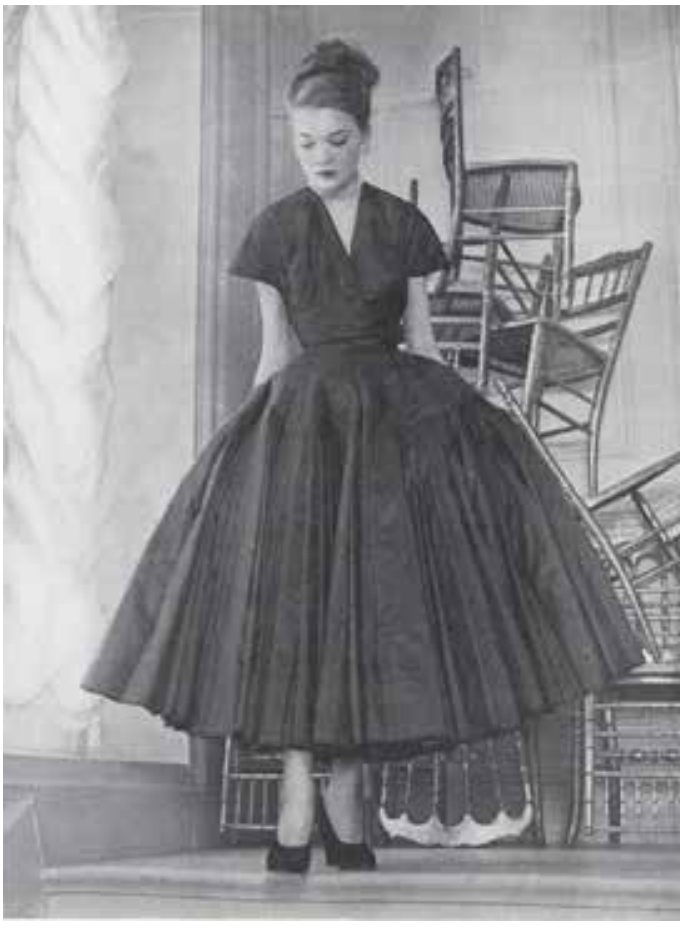

Figure 8: day dress, Christian Dior, Vogue, April 1947

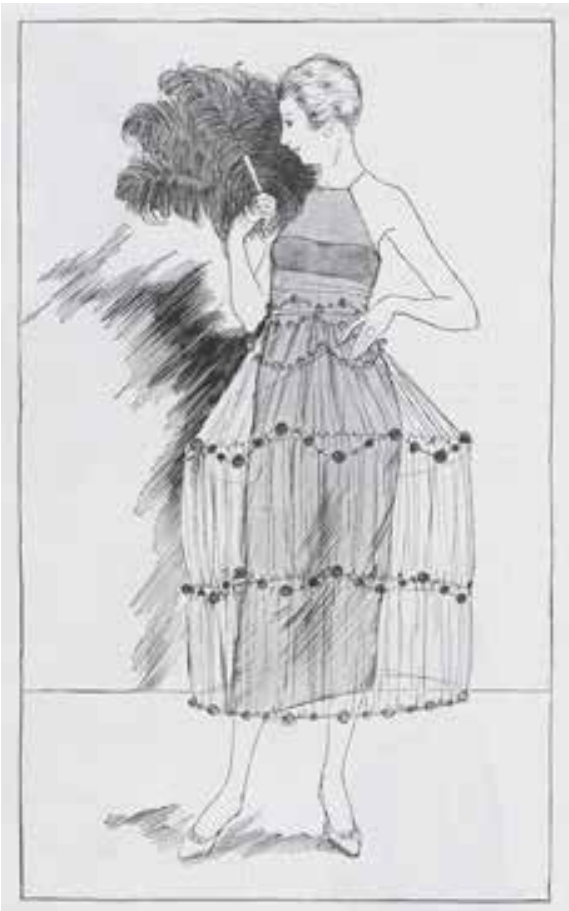

Figure 9: evening dress, Jenny, Vogue, April 1920 


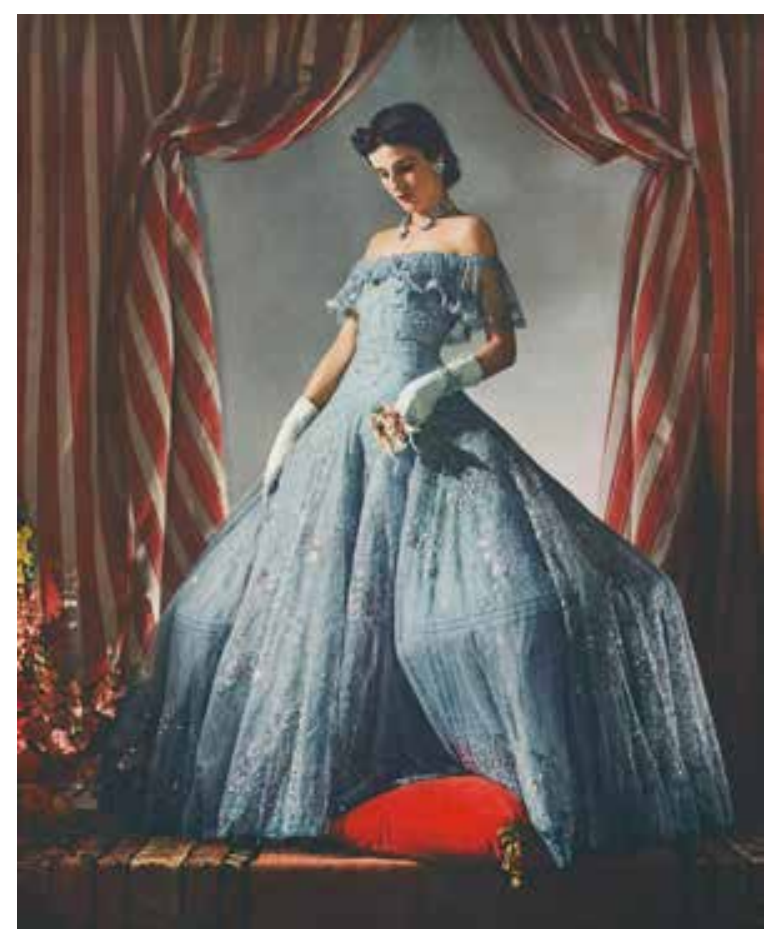

Figure 10: evening dress, Norman Hartnell, Vogue, May 1939

However, after 1947's New Look, a crinoline became a common sight in popular fashion for the first time since the late 1800s. In the 19th century, the silhouette went through two dramatic transformations: "the crinoline between 1845 and 1870, and the bustle between 1870 and 1890" (Bruna, p. 177). This era's hoop skirt and bustle were constructed with a steel structure, eradicating the whalebone that was used in the 18th-century pannier, a predecessor to the crinoline.

For the purpose of placing the Julian Rose hoop skirt within a larger historical context for the exhibition, I researched 18th and 19th century panniers, crinolines and bustles illustrated in Corsets and Crinolines (1954) and arrived at six distinct shapes for comparison purposes: 1) pannier or hoop petticoat from 1740; 2) pocket hoops from 1760 ; 3) cage crinoline from 1864; 4) cage crinoline with bustle from 1872; 5) long bustle from 1876; and 6) short bustle from 1887. The seductive volume of these sculptural skirts does bring an understanding of why exaggerated silhouettes were so tempting to the dressmakers in post-World War II Europe who had undergone a shortage of fabric and other commodities. These skirts are further illustrated in Chapter 3. 


\subsection{Precedent Study}

I selected two fashion exhibitions for my precedent study: 1) Charles James: Beyond Fashion and 2) The Concise Dictionary of Dress. These two exhibitions stood out for their modern take on dress display and spatial design. Both exhibitions eschewed highly theatrical strategies of display, and instead focused on communicating the materiality of the garments.

Charles James: Beyond Fashion ran from May 8th to August 10th of 2014 at the MMA. Curated by Harold Koda and Jan Glier Reeder, the exhibition focused on British-born, American couturier Charles James and his oeuvre of glamorous garments, from modern daytime suits to gravity defying evening gowns. The pared down exhibition was designed by New York-based art and architecture collective Diller Scofidio + Renfro. The exhibition "drew its power not from splashy imagery or transportive sets, but rather from the sheer force of James' incisive seams and sensual draping" (DeGregorio 493). The displays were designed to enhance the garment's artistic value, treating costume as sculpture, rather than a retail showcase. James' garments were displayed to be viewed thematically, rather than chronologically.

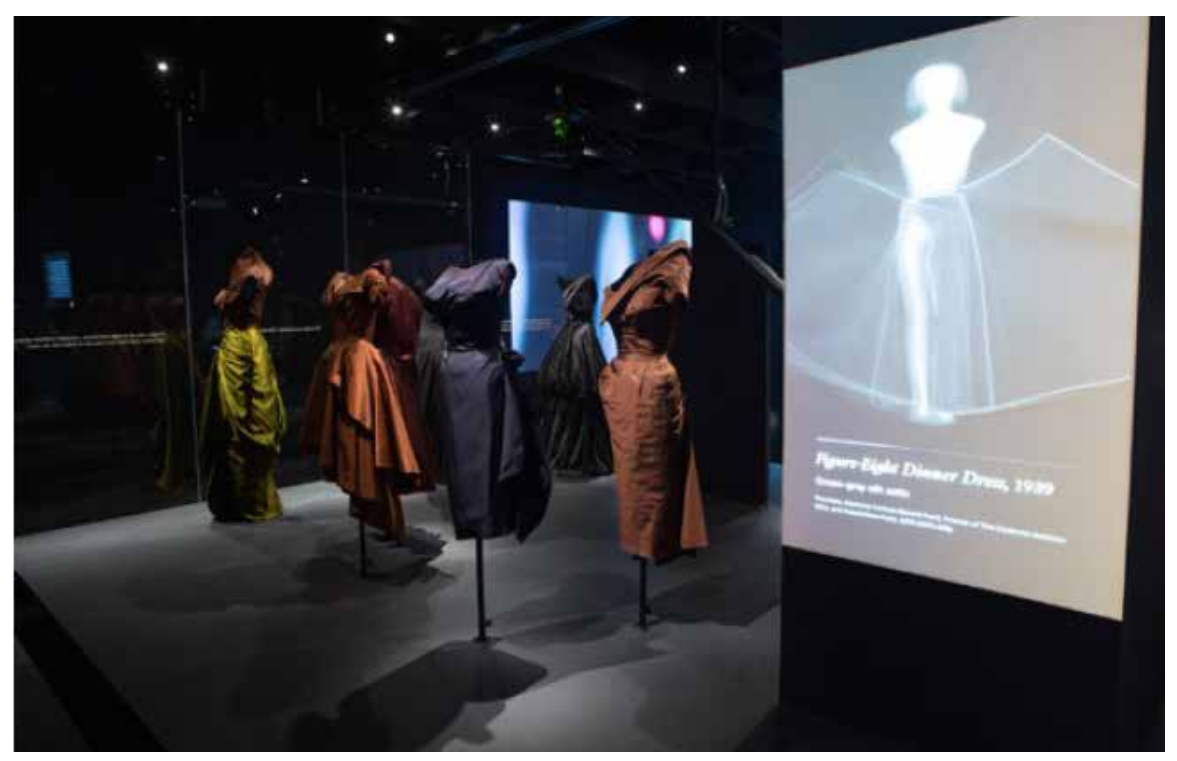

Figure 11: Charles James: Beyond Fashion

The Metropolitan Museum of Art, https://dsrny.com/project/charles-james 
Koda and Reeder separated James' technique into four groups: spirals and wraps; drapes and folds; platonic form; and anatomical cut (DeGregorio 496). Instead of standing on a plinth or within a vitrine, the garments were placed on "invisible" mannequins standing on thin black platforms, thus allowing the visitor an intimate connection with the intricate objects. Animated video clips showing construction were displayed on screens next to the group garments (Fig. 11). The twenty-six videos, which are archived on the museum's website, were highly sophisticated animations showing James' drapes and folds on the female figure.

Also incredibly advanced live scanning cameras were placed on robotic arms that offered x-ray views of James' most complex garments (Fig. 12). The x-rays revealed elaborate boning, hidden folds, and invisible stitching not visible on the exterior. The idea of $x$-rays was a brilliant one since there the viewer is unable to closely examine the construction and the anatomy of the garment due to strict the conservation policy of no touching.

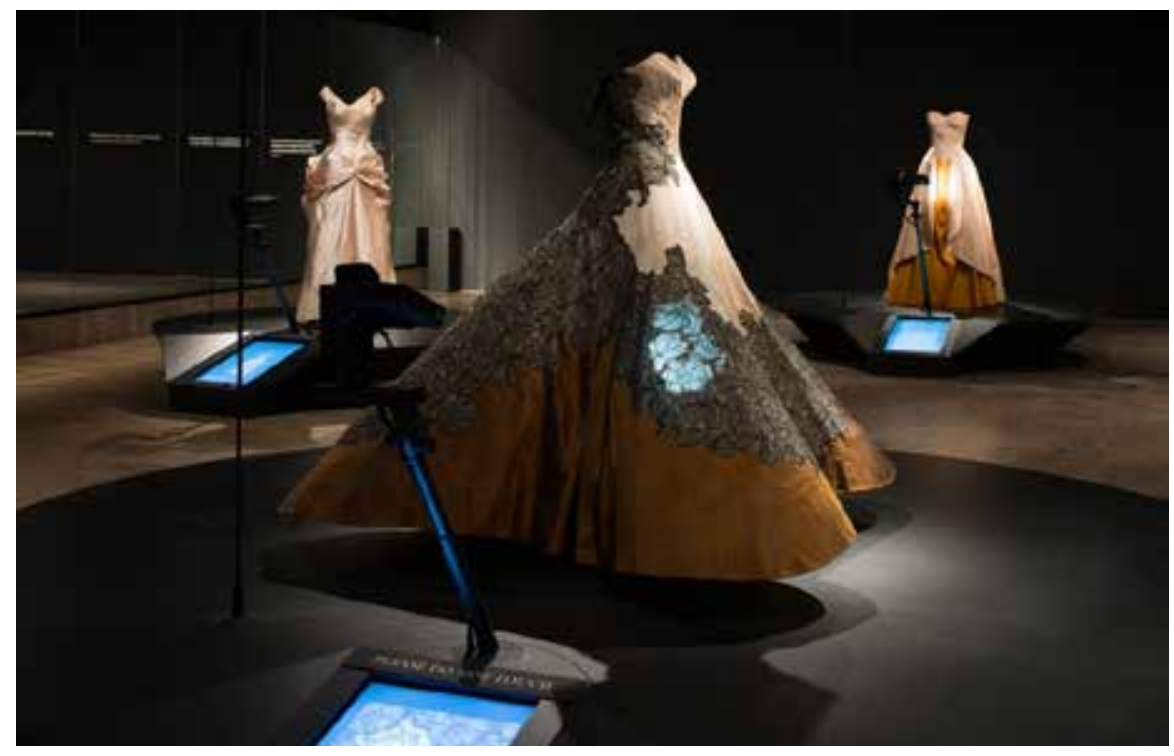

Figure 12: Charles James: Beyond Fashion

The Metropolitan Museum of Art, https://dsrny.com/project/charles-james

This exhibition had an almost clinical feel, since it was devoid of any decorative elements. The laboratory concept brilliantly captured the painstaking craftsmanship of Charles James. By revealing the complex layers of key garments, the designers and 
curators were able to bring the pieces to life, therefore allowing the viewer to imagine the labour of making them.

The Concise Dictionary of Dress ran from April 28th to June 27th of 2010 at Blythe House at the Victoria \& Albert Museum (V\&A). Commissioned by Artangel, a non-profit art production agency, the exhibition examined clothing as a series of definitions created by psychoanalyst Adam Phillips and accompanying installations designed by fashion curator Judith Clark. Blythe House, the working store for the museum's reserve collections, is a former headquarters of the Post Office Savings Bank in Olympia. Given the unique architectural features, Clark utilised some of the existing built environments such as the library stacks for the exhibition. In her most inspired move, Clark displayed draped eveningwear garments on one side of the stack, while the other side depicted their imprints in clay-a play on Greek and Roman sculpture (Fig. 13). This

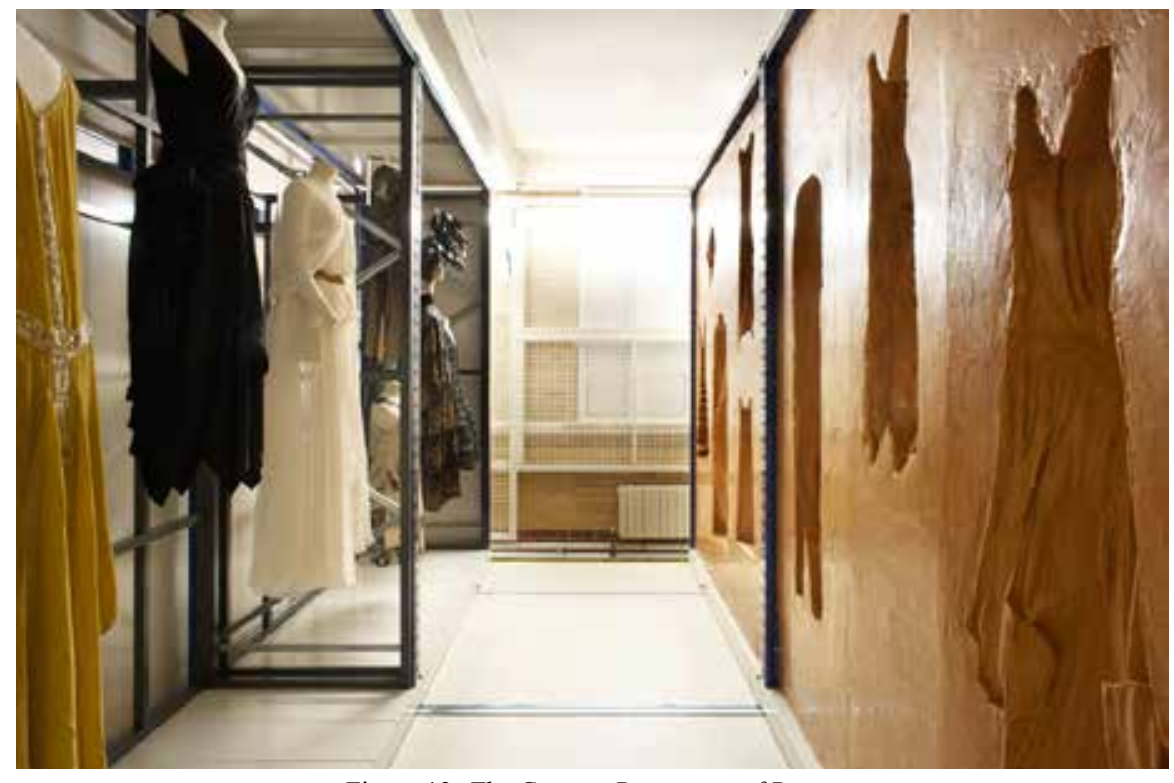

Figure 13: The Concise Dictionary of Dress

Victoria \& Albert Museum, https://frieze.com/article/concise-dictionary-dress

strategic move provided a solid, fossil-like artefact of each dress that communicated to the viewer all the textural intricacies that might be hidden by the garment's smooth fabric. Having an imprint of one half of the garment also allows the viewer to contextualise the volume of the dress, with its negative space giving off a ghost-like quality. In another display, one dress's intricate embroidery is extended to the wall as an enlarged ink 
drawing (Fig. 14). This allowed the viewer to appreciate the artistry of the embroidered layer on its own, without being bonded to the dress.

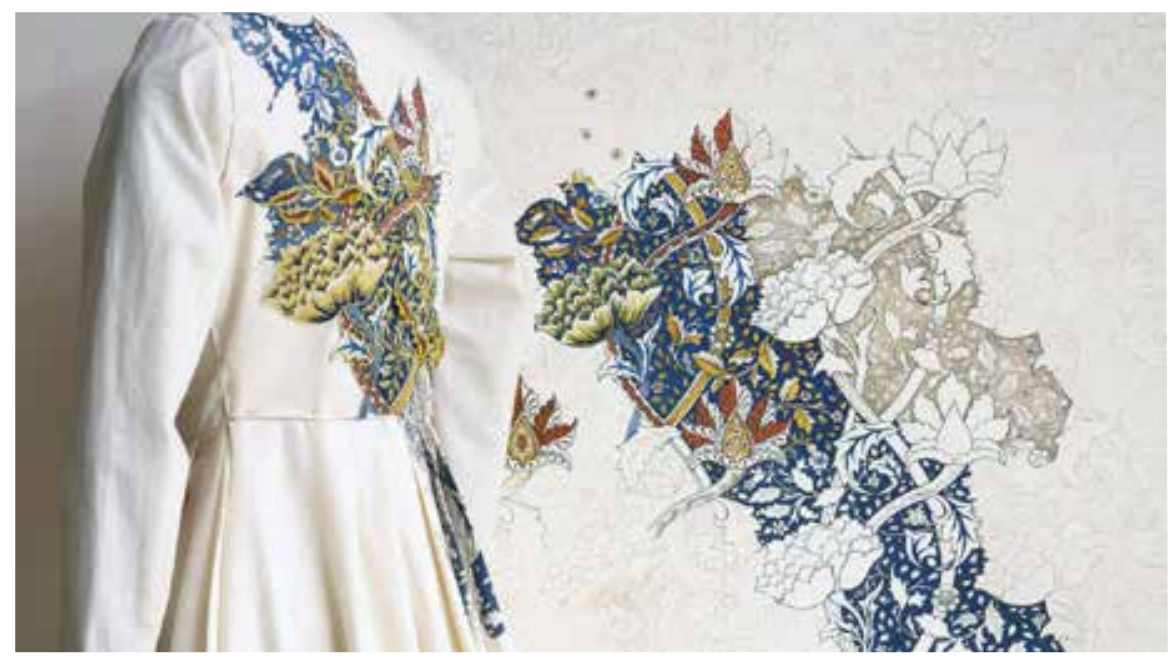

Figure 14: The Concise Dictionary of Dress,

Victoria \& Albert Museum, http://judithclarkcostume.com/exhibitions/the-concise-dictionary-of-dress/

In the accompanying publication, Clark explained that her priority in this exhibition was to depict the concept of an archive. "The archive is a very important ingredient here, as visitors do not expect garments to have been brought to life, but instead stored, classified and protected" (Clark and Phillips 110). There is an air of preciousness to the displays, as though one is looking through top-secret archival chambers. Similar to Charles James: Beyond Fashion, this exhibition did not rely on display conventions, using theatrical elements to place the garments in a historical context. Instead, the focus remained on each artefact and its place within in the theme of the exhibition.

Both exhibitions placed object-based research at the forefront. By choosing to focus on communicating the intricacies of each garment, the curators and exhibition designers created laboratory-like spaces without the fashion styling frills. This idea of an immaculate lab space played an important role when it came to my own exhibition design. What I took from my precedent study was the notion that deeper dress research can inspire multiple forms of display, including digital accompaniments and creative interpretations. 


\section{Chapter 3: Pavilion Design}

\subsection{Garment Rendering}

\section{Drawing}

I began a comprehensive object analysis by carefully measuring and drawing every detail of the garment. This process helped me better understand the intricacies of the garment construction. This was a difficult task since Ryerson Fashion Research Collection conservation standards did not allow for the dress to be flipped inside out, I had to carefully examine its construction and make best guesses for what I could not see. After an initial pencil sketch, I began drawing in Adobe Illustrator where I separated the dress into the following five layers: 1) hoop crinoline, 2) tulle layers 3) exterior satin layer, 4) embroidery, 5) and rhinestone embellishment (Fig. 15). The completed line drawing revealed complex dress construction that became the focal point of my visual display investigations.
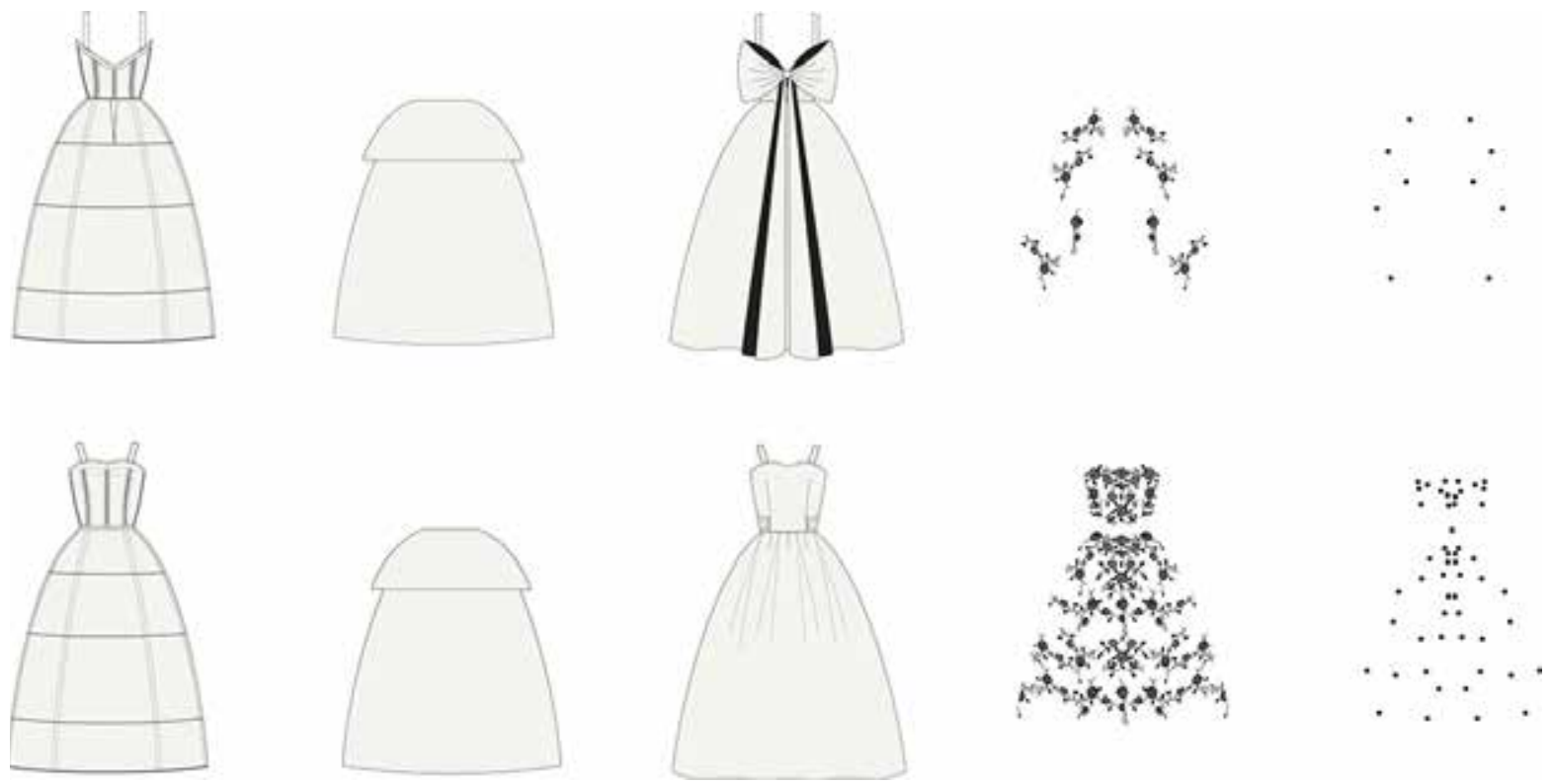

Figure 15: Dress layers: interior structure, tulle, exterior layer, embroidery, and rhinestone embellishment 


\section{X-ray}

Inspired by Charles James: Beyond Fashion, I decided that an x-ray of the garment would be a stunning visual piece in the exhibition. I got permission from Ryerson Fashion Research Collection curator Ingrid Mida to take the dress off campus, with her chaperoning. I contacted several non-destructive testing labs in the city, and C.B. Non-Destructive Testing Ltd. in Oakville seemed the keenest on the project. On the day of the appointment, Mida and I carefully drove the dress (Mida had a custom Tyvek garment bag built for the occasion) to Oakville.

Since the largest x-ray image plate was only 14 inches by 17 inches, the garment had to be photographed in several batches. We planned to lay down the dress on the table (Mida brought a large canvas sheet to keep the dress off dirty surfaces) as flat as possible, and simply move the plates down from the bodice to the skirt without moving the dress too much (Fig. 16). The technicians at the lab had never taken a garment $x$-ray, so we knew it was going to be a challenge. Between each take, we waited for the film to develop digitally.

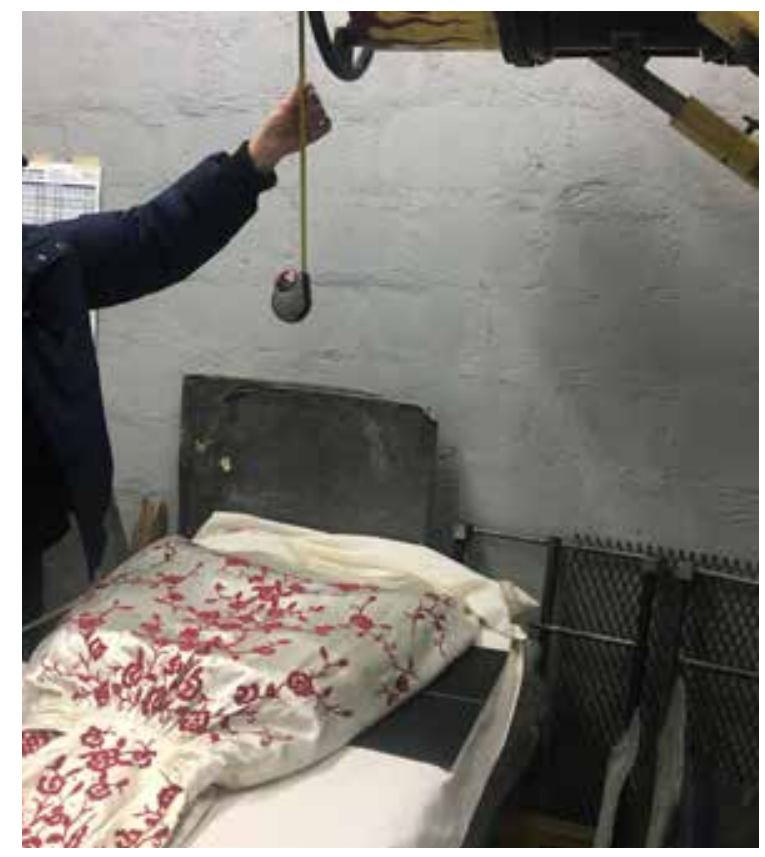

Figure 16: The dress on the x-ray table 
As soon as the first image of the bust (Fig. 17) popped up on the screen, it was apparent how dominant the boning structure was in the garment. When we photographed the skirt (Fig. 18), steel hoops visually overpowered everything else. I began to refer to these bones and hoops as the skeleton of the dress. However, I immediately began to notice new things about the more delicate layers. The image of the top of the skirt revealed that the tulle layer was actually made out of four sheets of tulle, two of which were cut short as peplum features. In my initial examination of the dress, I had completely missed this important detail. I later made that change to my drawings. The $\mathrm{x}$-ray also revealed that one of the steel hoops was broken with its two ends no longer attached.

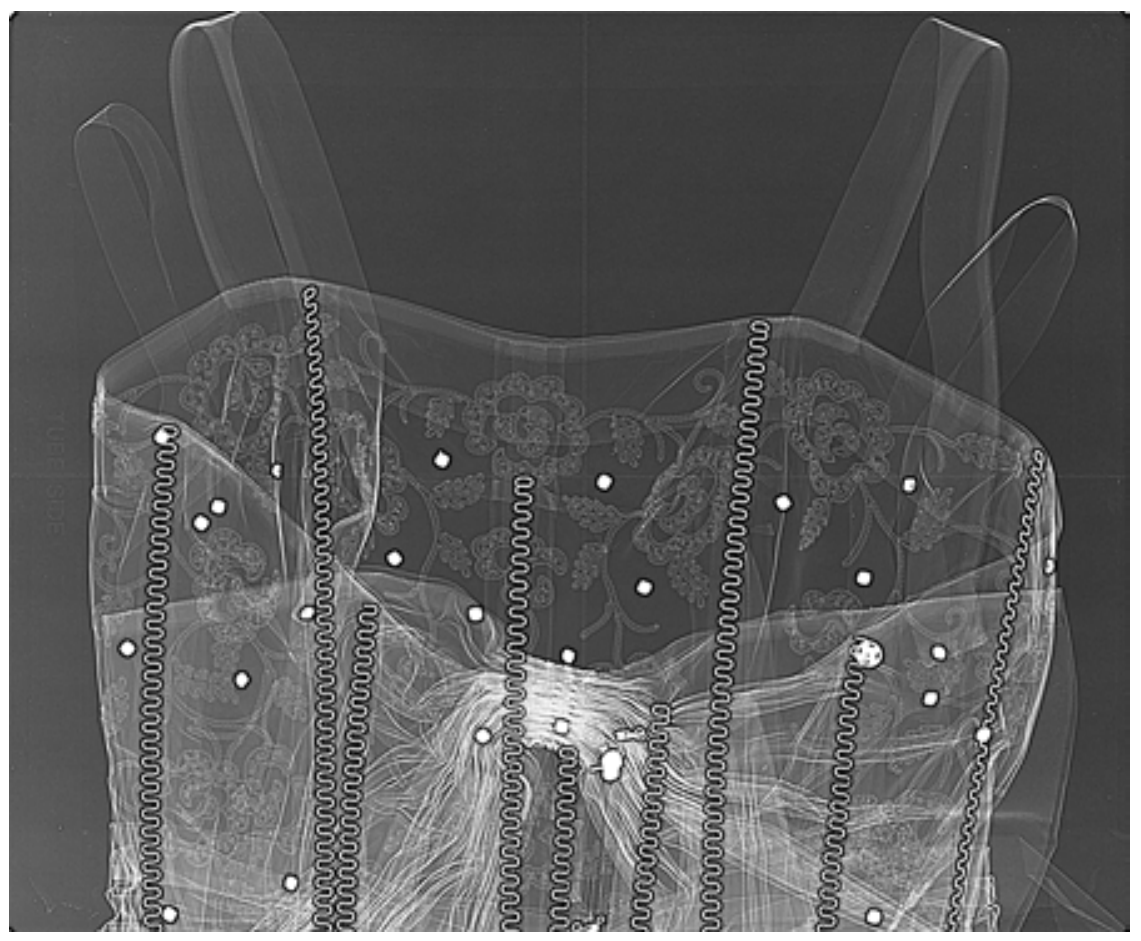

Figure 17: Bodice x-ray

Unfortunately, by the time we got to the wide part of the skirt, it became too broad for the scope of the x-ray "lens", and we had to physically pick up the dress and move it in a different direction. This caused a lot of fabric shifting, and once I went home to stitch the plates together in Adobe Photoshop, they just did not line up. Still, the final 
stitch (Fig. 19) was an incredibly revealing, seductive element to include in the exhibition. It showed the anatomy of the dress that was both clinical in its nature and gorgeous to look at.

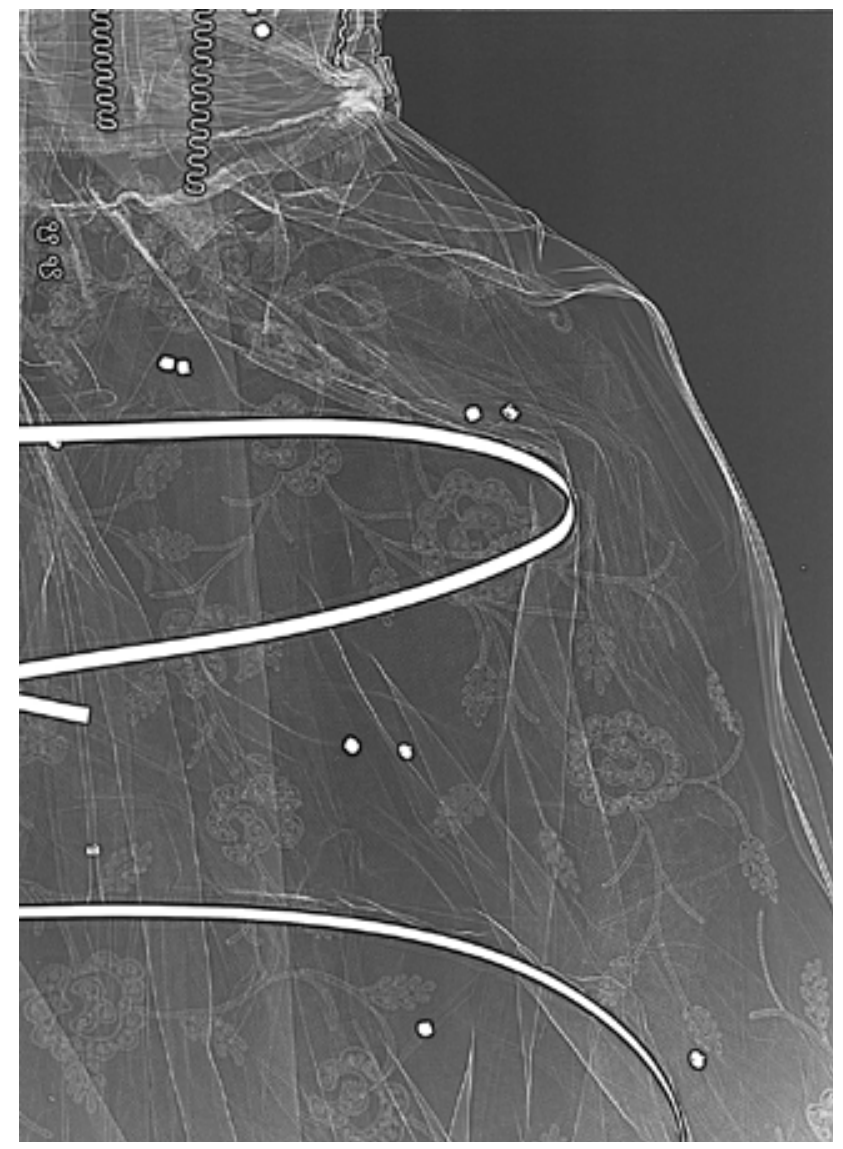

Figure 18: Skirt x-ray

Taking cues from Clark's work in The Concise Dictionary of Dress, I wanted to sculpturally represent each layer in space so that the viewer can visually enjoy each aspect of the garment. I desired to express this spatially, something that the viewer can walk through, beginning at the outer surface and moving towards the utmost inner layer. I wanted to use the x-ray as a mediation point between the exterior and the interior of the dress. What became apparent from the drawings was that when I isolated the rhinestones and the embroidery layers, they both still retained a visual silhouette of the dress. This became an intriguing concept: What would happen if those details were peeled away from the dress? 


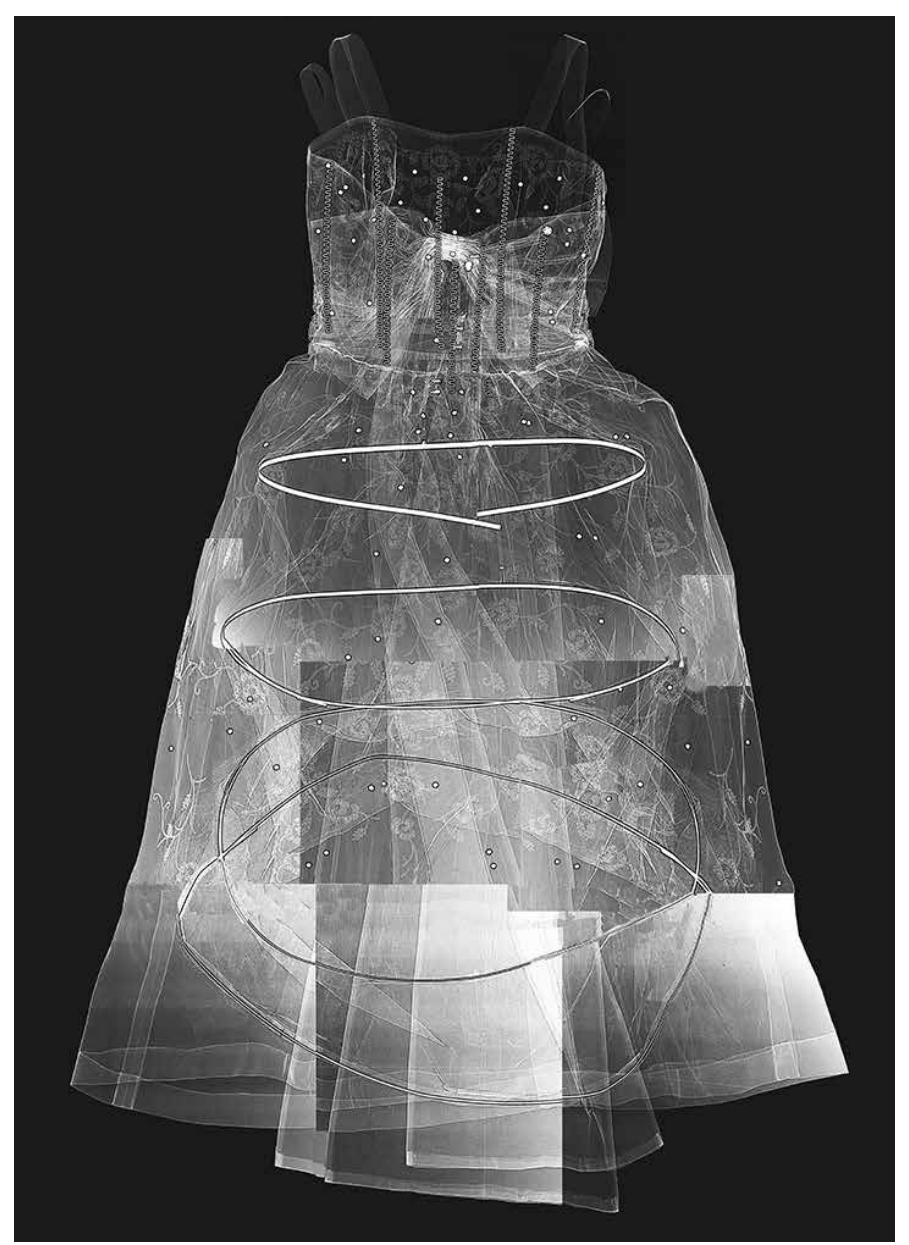

Figure 19: Dress x-ray

\section{Study Models}

My spatial investigation began with small 1:100 scale paper models (Fig. 2021). With these, I started to imagine the viewer's experience and how they would move through each display panel. In my initial 1:25 scale materials study (Fig. 22-23), I began to think about the materiality of those display panels. The first two panels were imagined as frames from the delicate embellishment layers, while the other three were pictured as solid, fabric-like panels. The sequence of the panels was designed to enhance the viewer experience: starting with the exterior of the dress and working towards the interior (Fig.11). The rhinestones were imagined as tiny glass beads that hung from the top of the frame. The embroidery was conceived as 3D-printed objects hung together, creating a silhouette of the dress. The middle panel became the x-ray panel, letting the viewer 
know that they were now entering the inside of the dress. Next, tulle layers were sculpturally extruded from the flat drawing on the panel, so that the viewer could understand the volume involved in a dress like this. And, finally, the skirt's skeleton was reconstructed using bent sheets of plastic, to reveal the most intimate structure of the dress.

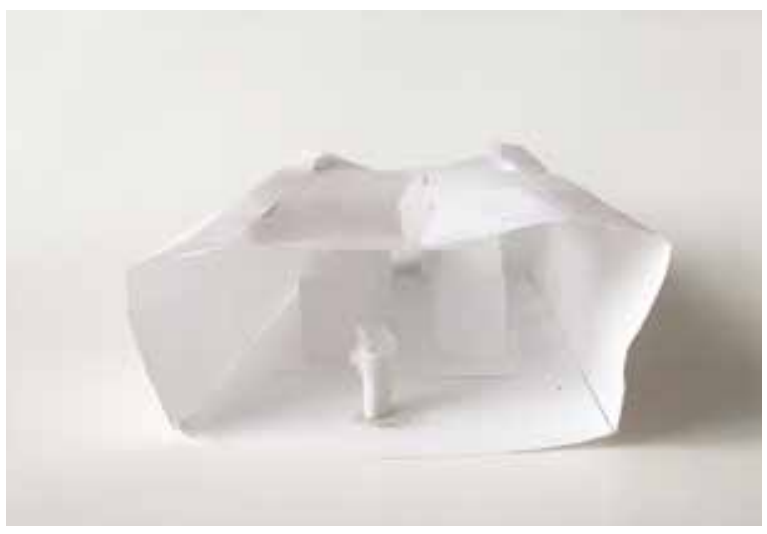

Figure 20: Study model

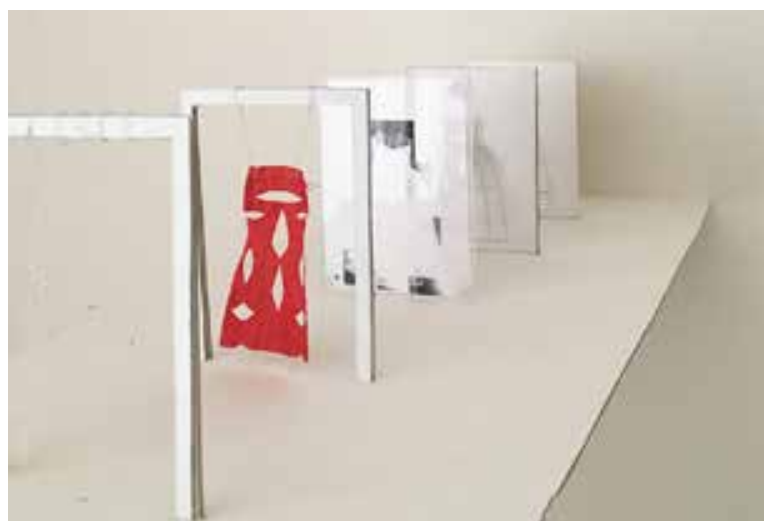

Figure 22: Study model

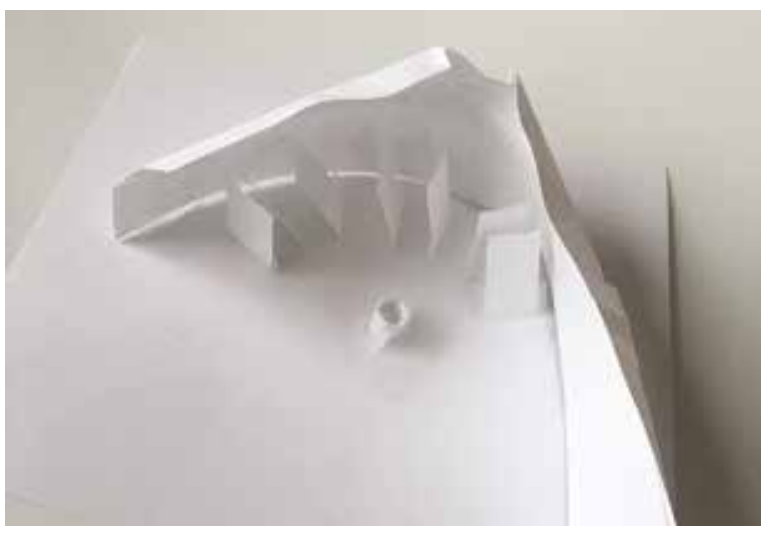

Figure 21: Study model

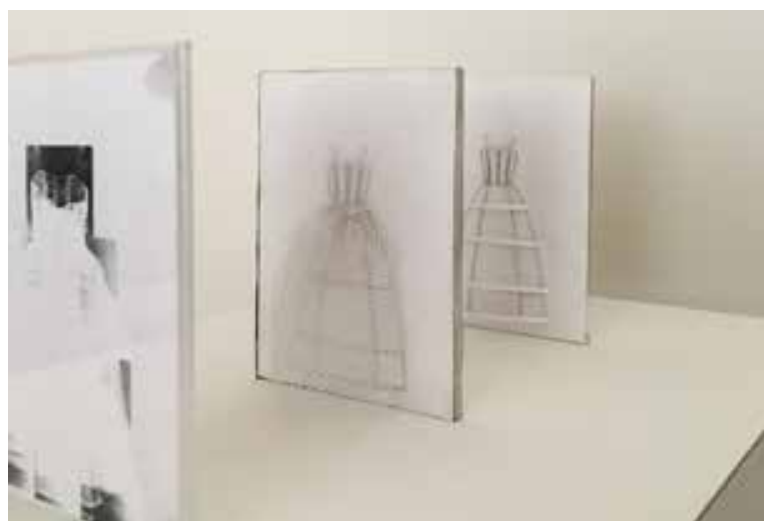

Figure 23: Study model

\section{Final Rendering}

The same sequence was kept for the final model, which became much more intricate in its materiality, to best represent what the displays would look like if they were full size. I also wanted to include the back views of the dress on an additional five panels, placed next to each other. I laser cut a total of ten acrylic panels (Fig. 24), frosted for the first two and last two layers on each side, and transparent for the $x$-ray layers. Since hanging of artefacts was required for the frame-like panels, I incorporated small laser cut holes at the top to allow for threading of the hanging material. 


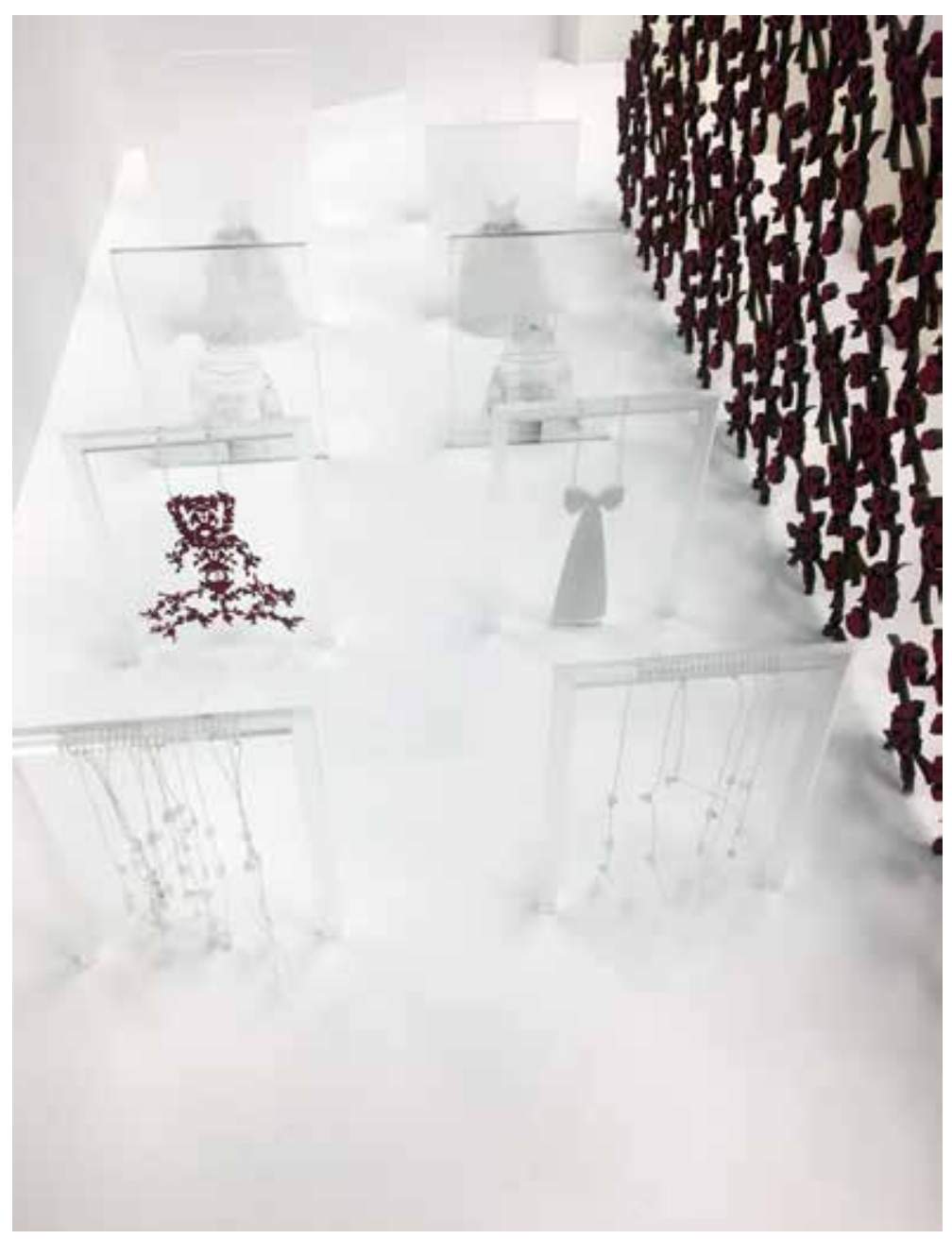

Figure 24: Acrylic panels depicting dress layers

For the first front and back panels (Fig. 25), I individually strung each bead onto the thread instead of real-life rhinestones to match the scale of the model. This worked out beautifully as the faint silhouette appeared as a result. For the second front panel (Fig. 26), I laser cut the embroidery with a red sheet of paper and strung it together. Like the rhinestones, this delicate layer resulted in a ghost-like appearance. For the back panel, I decided to skip the embroidery since the bow was much more prominent. For this, I teamed up with a 3D modelling artist Jenny Bermas who modelled the bow, the dress, and the rest of the garments in Maya software for 3D printing purposes. I then strung the 3D-printed bow from the frame. The bow (Fig. 26), unlike the embroidery, appears really sturdy, and thus communicated its significant volume in the garment. 


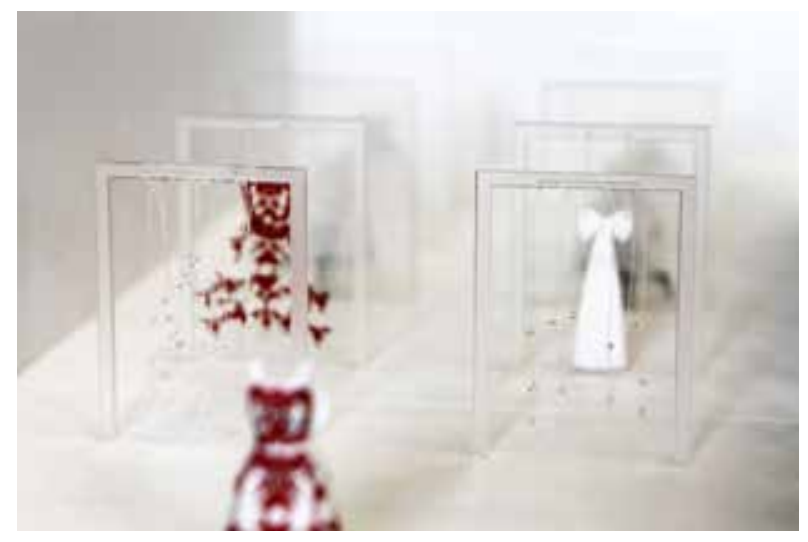

Figure 25: Beaded panels

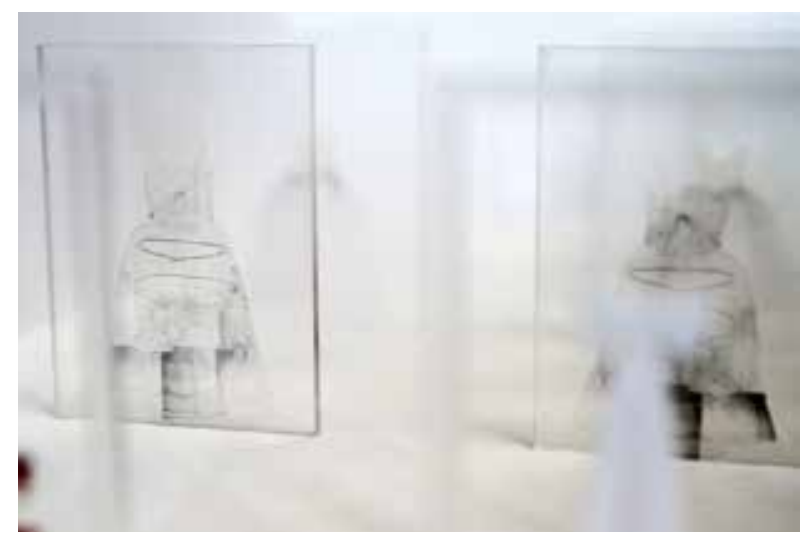

Figure 27: X-ray panels

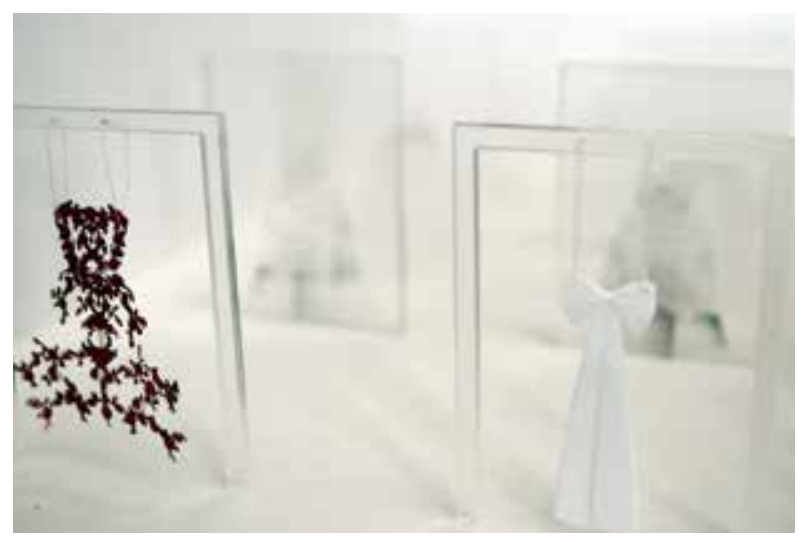

Figure 26: Embellishment panels

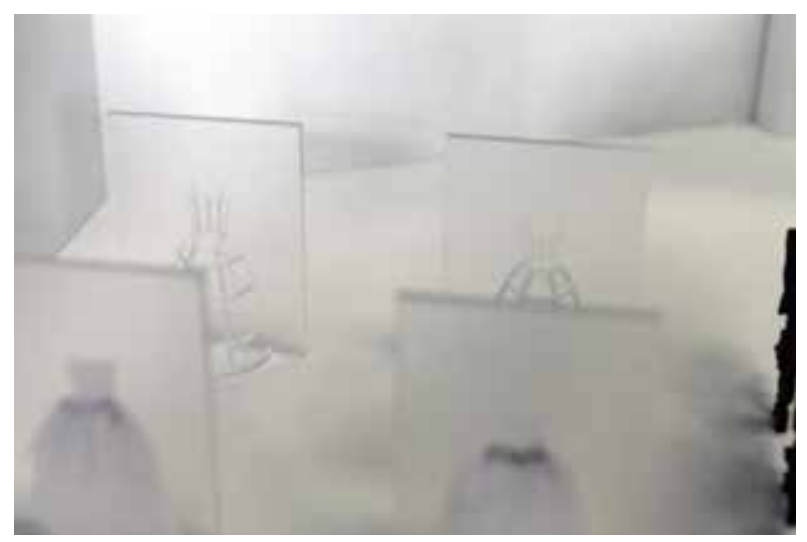

Figure 28: Tulle and structure panels

The next two panels show the x-ray (Fig. 27). I added a touch of colour in Photoshop so that it's more clear when one is looking at the front versus the back. I used the Burn and Dodge tool to bring the dress's bones forward for each view. I also inverted the colour to make the $\mathrm{x}$-ray lighter to see through, since the sequence was designed with that purpose. When the viewer is looking at the first two layers of rhinestones, embroidery and the bow, they can see the x-ray down the line as a reference point. The $\mathrm{x}$-ray also positions the viewer at a threshold between the interior and the exterior.

For the fourth front and back panels (Fig. 28), I laser etched the silhouette of the dress on a frosted sheet of plexiglass. I then sewed the two front and back halves of the tulle layers and attached it to the panel. The tulle layers are completely hidden under the satin and create an incredible amount of volume. And for the final panels (Fig. 28), I etched my technical interior drawing to frosted plexiglass. I then 3D-printed the hoop 
skirt, attaching the front half to the panel representing the front, and the back half of the panel representing the back. These last two panels really speak about the bones of the dress, so that the viewer can experience it in an almost clinical way, like a skeletal artefact in a museum.

\subsection{Spatial Design}

Working with architectural drawings (Fig. 29), and later the model (Fig. 30), I laid out the ten panels first, five on each side, with plenty of space to move around the middle and the panels. This long, lens-like strategy provided the space for the main exhibition (Fig. 31). Once I placed the Julian Rose gown in front of it, I knew that the entrance to the exhibition needed to be clearly defined. The placement of the angled wall at the front provided a coherent entrance point and a space for the curatorial statement and introductory display. Once the viewer moved through the Julian Rose space, they end up at the beginning of the hoop skirt exhibition (Fig. 32).

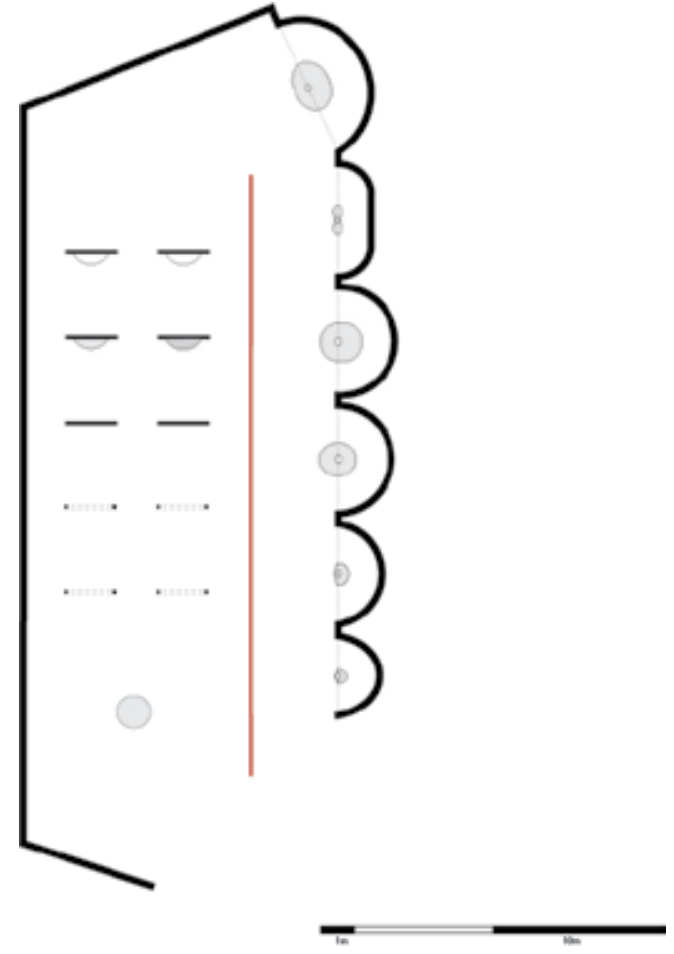

Figure 29: Pavilion plan

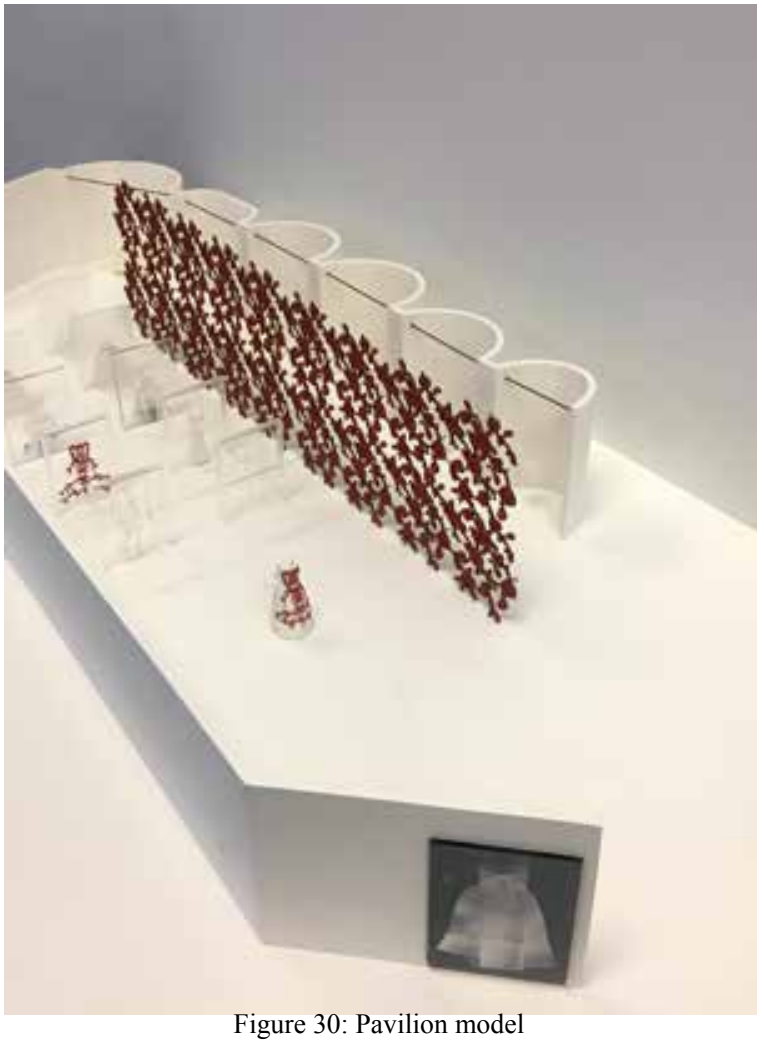

Figure 30: Pavilion model 


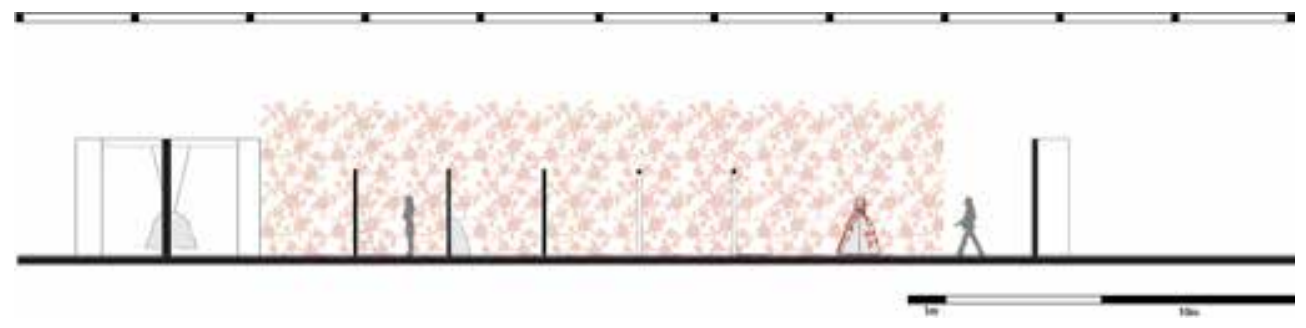

Figure 31: Sectional view of the dress gallery

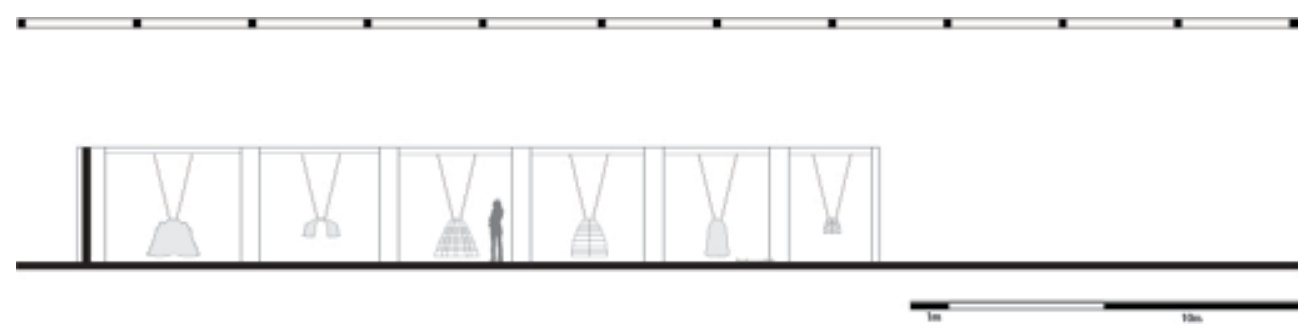

Figure 32: Sectional view of the hoop skirt gallery

This exhibition was meant to provide a brief history of hoop skirts that would have predated the Julian Rose gown. I had the six underskirts -1 ) pannier or hoop petticoat from 1740 ; 2) pocket hoops from 1760; 3) cage crinoline from 1864; 4) cage crinoline with bustle from 1872; 5) long bustle from 1876; and 6) short bustle from 1887 - from Corsets and Crinolines (1954) 3D modeled by Jenny Bermas for 3D printing. For this part of the exhibition, I imagined these objects as 3D-printed as well, so that they could perhaps be touched and interacted with.

Inspired by Clark's library stacks with clay dress imprints in "The Concise Dictionary of Dress," I wanted to create an individual space for each skirt, one that would respond to its shape. I took the 3D-modeled skirts into Rhinoceros modelling software and traced a line around each skirt, and then extended the lines into walls to create pod-like environments for each artefact. These pods, large enough for the person to walk around each skirt, were placed in chronological order (Fig. 32), starting with the 1740 pannier and ending with the 1887 bustle. These intimate spaces were designed to exaggerate the notion of how much room the hoops would have taken by forcing the viewer to walk around their volumes while navigating the wall parameters. 
A long 17-metre red lattice wall that mimics the embroidery of the dress divides the two galleries (Fig. 30). The perforations in the wall allow the viewer to peek at the hoop gallery while in the main space. Its composition is derived by tracing an outline of the select embroidered roses, and then attaching them together in a continuous vine motif. The larger scale of the roses exaggerates the dress embroidery to provide a spatial experience of looking through sizable perforations.

\subsection{Exhibition Walkthrough}

The pavilion is designed with a clear sequential flow in mind (Fig. 33). As one approaches the front on the pavilion, they are greeted with the oversized x-ray of the Julian Rose gown that is situated in a light box next to the exhibition title, "Anatomy of a Dress" (Fig. 34). Once they enter into the pavilion, they find themselves in front of the physical dress, with a curatorial statement on the angled wall on the right side. The statement reads:

"In the 1950s, the female silhouette changed drastically from broad-shouldered, boxy shapes to so-called feminine fashions of nipped waits and full skirts. The shift was in part spawned by the popularity of Dior's New Look of 1947, although it could be argued that the nostalgia for the silhouette never went out of fashion, having appeared in Vogue regularly since the end of World War I. By the 1950s, most dressmakers have adopted the silhouette.

This Julian Rose dress shows how Haute Couture construction techniques were adapted in the ready-to-wear realm. Not much is known about Julian Rose today, but he was a prominent London-based designer in 1950s. Often featured in British Vogue, his designs beautifully captured the mood from the Paris runways for a much friendlier price tag. The complex construction of this gown exhibits elegant solutions in achieving sculptural volume and drama. Here, each layer is peeled away for a closer investigation."

This space also houses a chronological "build up" to the 1950s crinoline craze, with historical photographs from Vogue outlined in Chapter 2 (Fig. 35). 


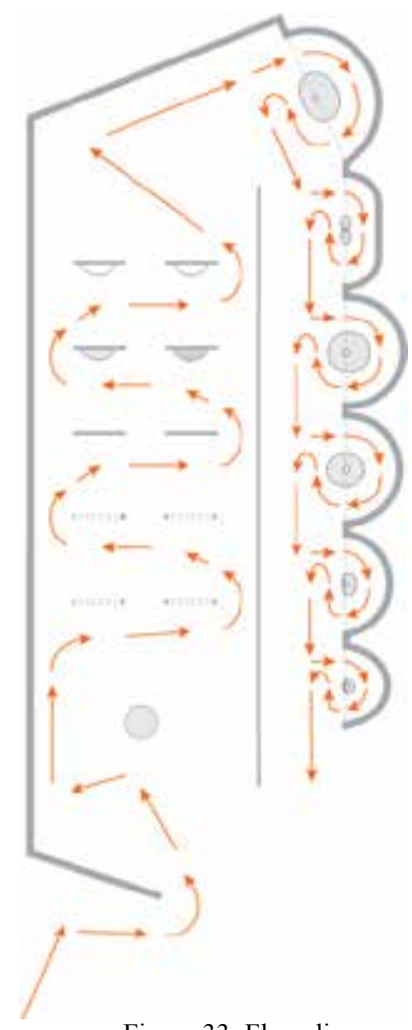

Figure 33: Flow diagram

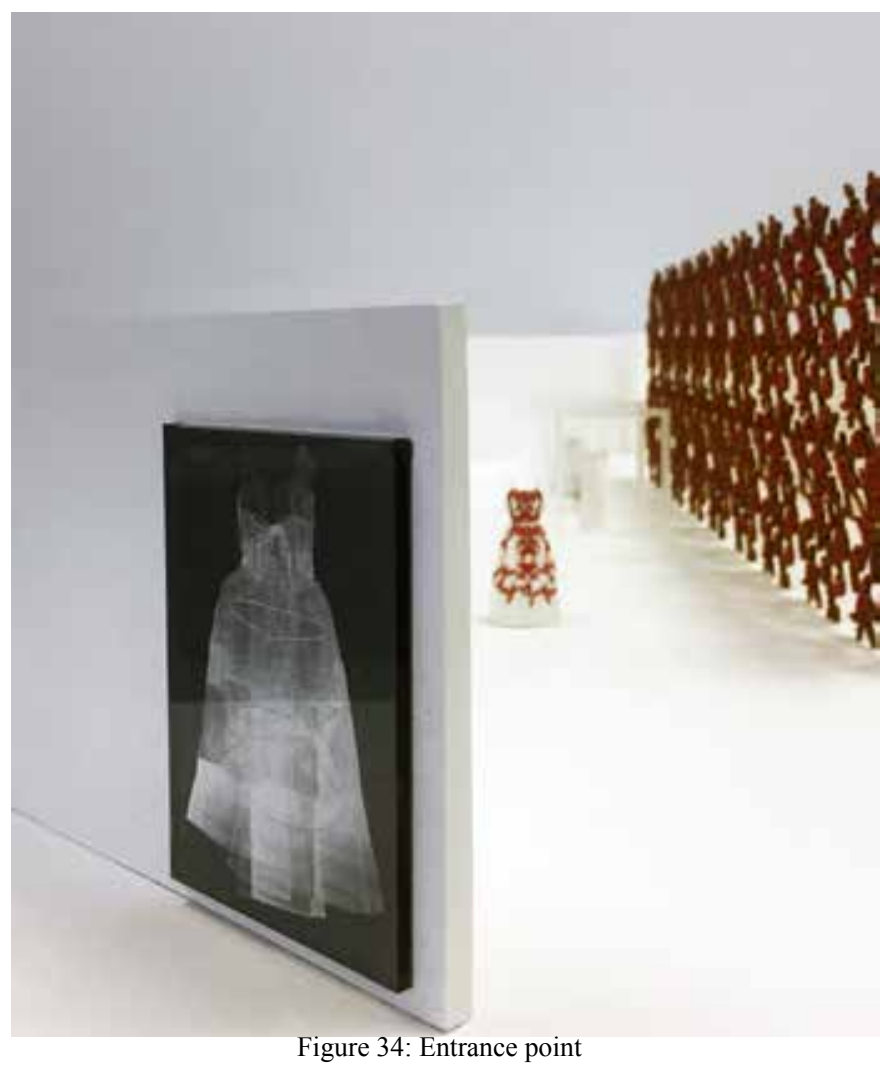




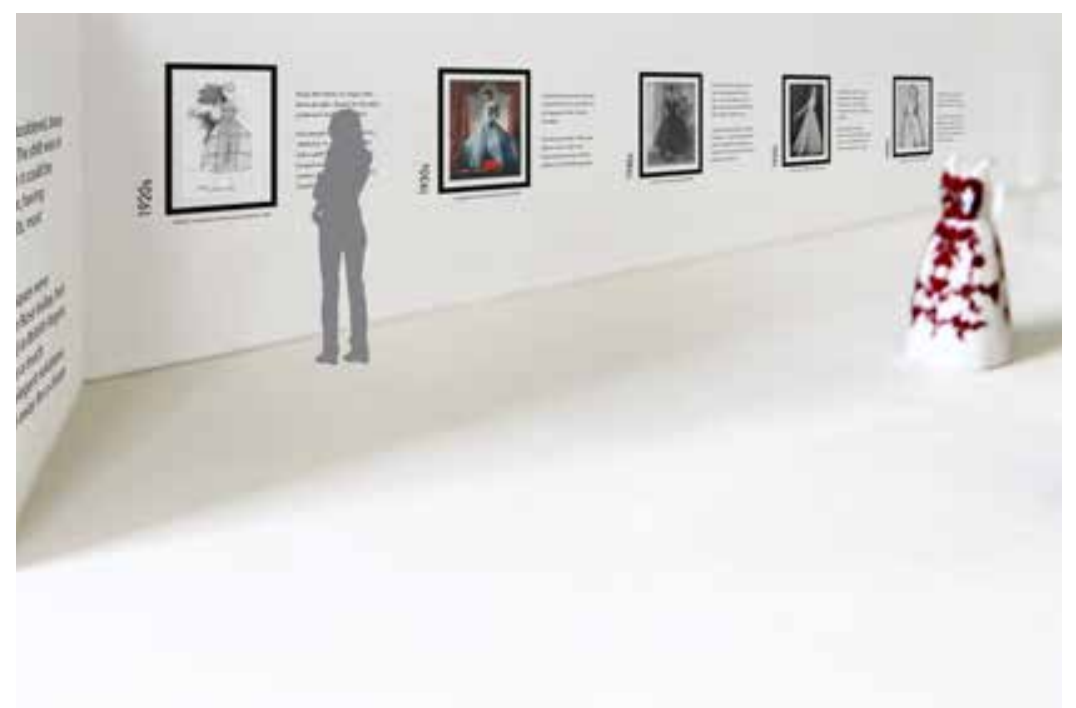

Figure 35: Crinoline timeline, 1920s-1960s

Once the viewer is given a base explanation, they begin the journey through the dress layers, meandering between front and back panels of the dress, starting with the exterior embellishment and ending with the most intimate layers of the dress anatomy (Fig. 32). This space is imagined almost like a laboratory, with panels as microscopic plates. As the viewer moves through this space, they catch a glimpse through the rose lattice wall of the continuing exhibition. Where the journey through the dress ends, the hoop skirt exhibition begins.

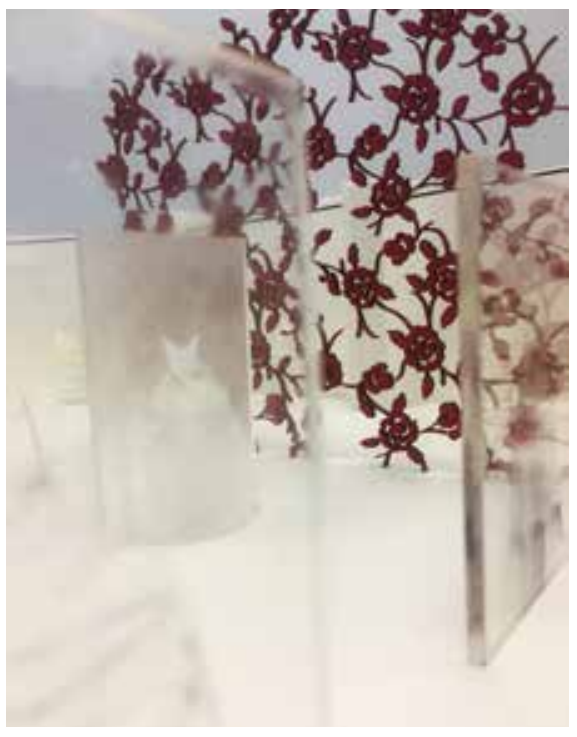

Figure 36: Dress anatomy panels 
The viewer finds themselves in a transitional space that introduces the history of a crinoline (Fig. 37). The statement of the wall reads:

"Voluminous skirts ruled women's fashion for four centuries, starting with the Spanish farthingale in the mid-1400s and ending with a short bustle in the late 1800 s. These undergarments not only provided volume but also gave the wearer a sense of modesty. The farthingale was a hoop skirt stiffened with the subtropical Giant Cane, and later willow cuttings, rope, and, finally, whalebone in the late 1500 s. In the late 1600s, the boxy pannier or side hoops replaced the circular shape. These whalebone supported underskirts were flat in the front and ample on the sides.

By the 1850s, whalebone was replaced with steel, and the cage crinoline was invented. While the earlier crinolines were stiffened with horsehair ("crin"), the cage crinoline freed the wearer from copious amounts of petticoats. Later, a bustle was added to the circular shape. The cage crinoline's popularity was short lived and by the 1870 s, most women were wearing bustles. They too ended their reign rather quickly, and before the turn of the 20th century, most women rejected the structured underskirts.

This exhibition begins with three pre-18th century depictions of crinolines before it turns the corner to the physical skirts (Fig. 37). These skirts are 3D printed objects that are situated within their own pods (Fig. 38-39). The pods' shapes respond to the shape of each skirt, allowing the viewer to experience the space shaped by their volumes as they walk around them. By understanding the volumes through such intimacy, the viewer can comprehend the embodied experience of what would it feel like to wear one. The red lattice wall acts as a mediator between the two galleries, a constant reminder of the Julian Rose dress as the primary focus of the exhibition (Fig. 39). When the viewer has experienced the last bustle, the end of the red lattice wall leads them back to the beginning of the exhibition (Fig. 40) where they have an option to repeat the experience. 


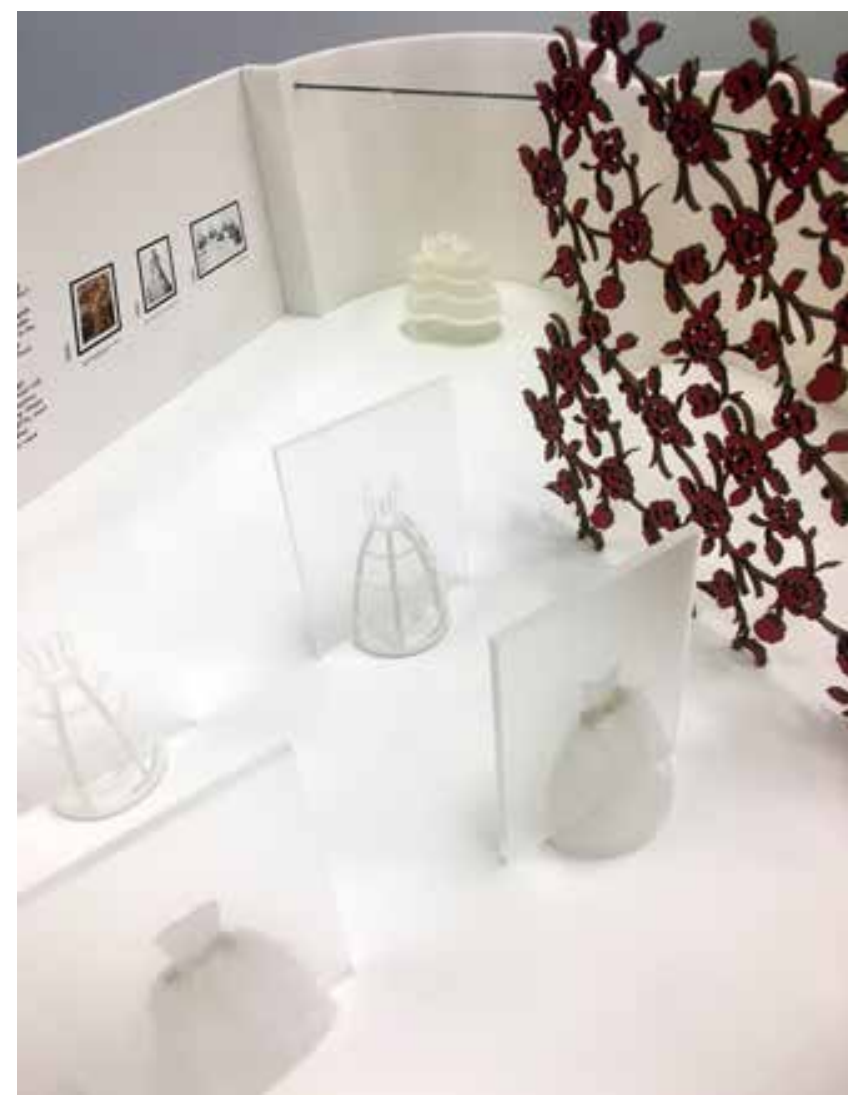

Figure 37: Transitional space

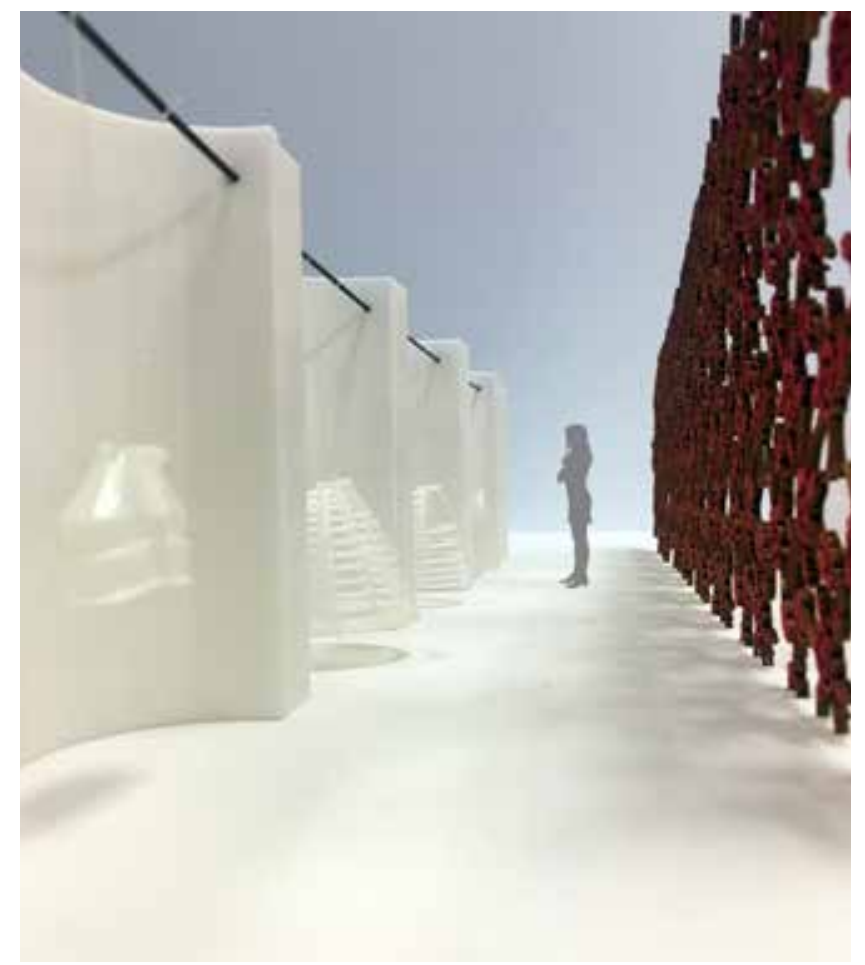

Figure 38: Hoop skirt gallery 


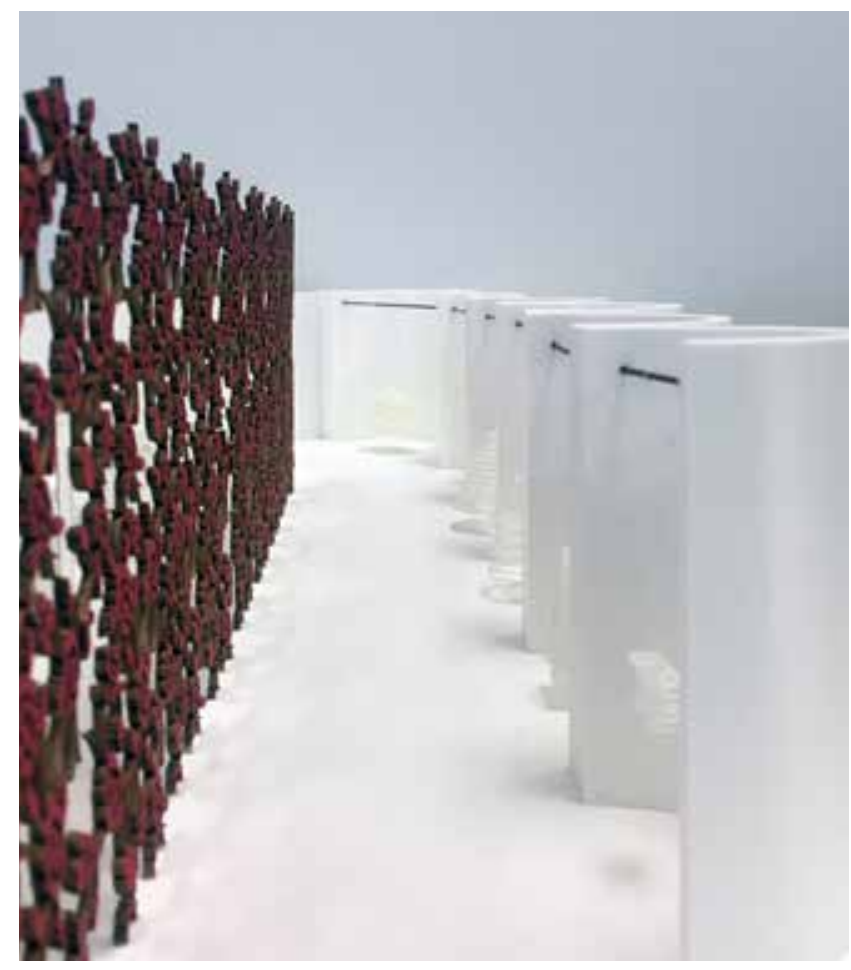

Figure 39: Hoop skirt gallery

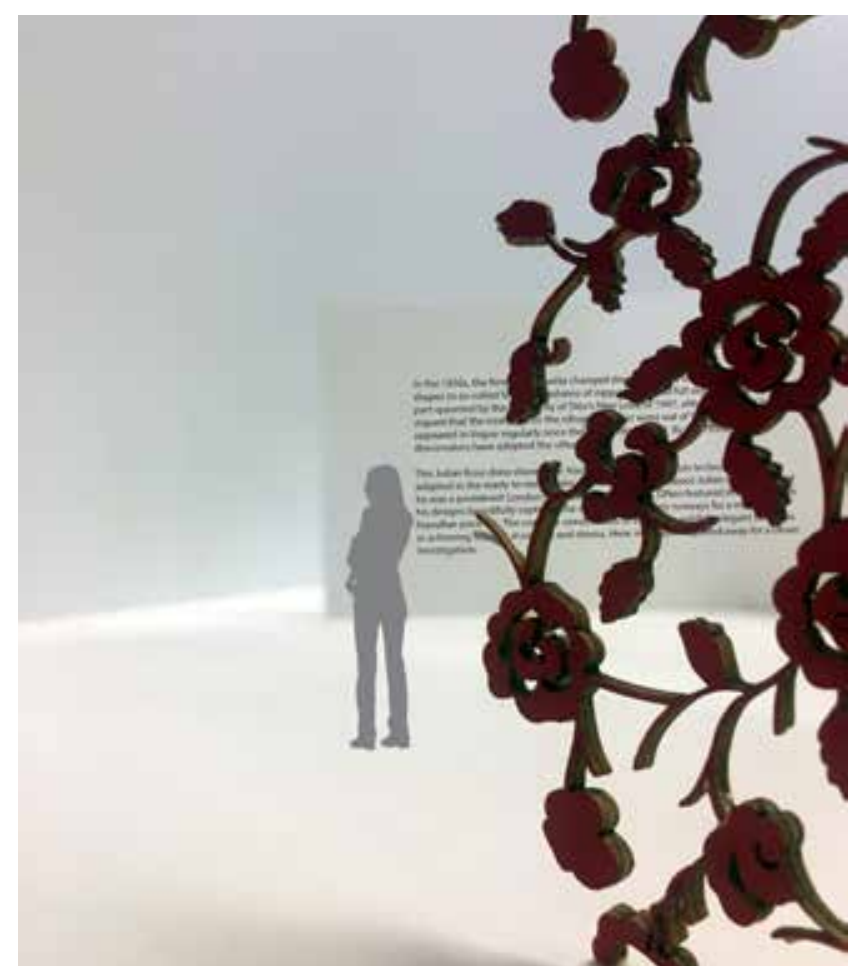

Figure 40: Exit and entrance point 


\section{Conclusion}

Anatomy of a Dress provides an example of how object-based research can lead to spatial design. Aside from Charles James: Beyond Fashion, very few exhibitions delve into the fine detailing of dress construction. While I worked on this project, the Royal Ontario Museum (ROM) held Christian Dior, an exhibition curated by Alexandra Palmer that focused on the luxury label's first ten years in business. The exhibition was predictable in its display: garments were mounted on dress forms, all construction labour hidden under their exterior layers. On the iPads next to the garments were small interior photographs of some of the dresses, the only indication of the complexity and beauty of their anatomies. It was a missed opportunity in educating the viewer of the genius construction techniques of the designer who changed the women's silhouette with his New Look. However, the ROM produced an engaging video for their website called "Decoding Dior's Delphine" that depicted a replication of one of the iconic dresses by the garment construction team at George Brown College. The video showed the painstaking labour that went into the production of the dress. Unfortunately, this important object-based research was not shown in the exhibit.

The design of my exhibition completely relies on physical and embodied object-based analysis, rather than the spectacle. It is imagined as a laboratory where the dress is put under a microscope. Through careful examinations in form of technical drawings, x-rays, and 3D fabrication, I was able to deconstruct the essence and the meaning of the dress. My investigations also touch upon how a garment can inform interior space, by physically shaping it with its volume. The spatial interpretation of the dress and its historical context can be looked at as a continuation of Mida and Kim's three-step methodology for object-based research. Perhaps intimately knowing how something is made can help the viewer imagine the embodied experience of wearing the garment, a way of animating the dress without the need for live bodies. 


\section{Bibliography}

Black, Alexandra. The Evening Dress. Rizzoli, 2004.

Brooks, Mary M., Dinah Eastop, and Getty Conservation Institute. Refashioning and Redress: Conserving and Displaying Dress. The Getty Conservation Institute, Getty Publications, 2016.

Bruna, Denis, and Bard Graduate Center: Decorative Arts, Design History, Material Culture. Fashioning the Body: An Intimate History of the Silhouette. Published for Bard Graduate Center, Decorative Arts, Design History, Material Culture, 2015. Clark, Judith, Adam Phillips, and Artangel. The Concise Dictionary of Dress. Violette Editions in association with Artangel, 2010.

Clark, Judith, Amy De La Haye, and Jeffrey Horsley. Exhibiting Fashion: Before and After 1971. Yale University Press, 2014.

Come Step Back in Time. "1950s Britain - Part Three." 26 May, 2012. Retreived from https://comestepbackintime.wordpress.com/tag/1958-the-fashion-house-groupof-london/

DeGregorio, William. "The Architecture of Woman: Charles James: Beyond Fashion, Metropolitan Museum of Art, New York, may 8-August 10, 2014."

Fashion Theory, vol. 19, no. 4, 2015, pp. 491-503.

Entwistle, Joanne. The Fashioned Body: Fashion, Dress, and Modern Social Theory. Polity Press, 2015.

Koda, Harold, and Jessica Glasscock. "The Costume Institute at The Metropolitan Museum of Art: An Evolving History." Fashion and Museums: Theory and

Practice. Ed. Marie Riegels Melchior and Birgitta Svensson. London: Bloomsbury Academic, 2014. 21-32.

Koda, Harold, et al. Charles James: Beyond Fashion. The Metropolitan Museum of Art, 2014. 
McNeil, Peter. "'We'Re Not in the Fashion Business": Fashion in the Museum and the Academy." Fashion Theory, vol. 12, no. 1, 2008, pp. 65-81.

Melchior, Marie R., and Birgitta Svensson. Fashion and Museums: Theory and Practice. Bloomsbury USA, 2014.

Mida, Ingrid. "Animating the Body in Museum Exhibitions of Fashion and Dress." Dress, vol. 41 , no. 1,2015 , pp. 37-51.

Mida, Ingrid, and Alexandra Kim. The Dress Detective: A Practical Guide to Object-Based Research in Fashion. Bloomsbury Academic, an imprint of Bloomsbury Publishing Plc, 2015.

Palmer, Alexandra. "Untouchable: Creating Desire and Knowledge in Museum Costume and Textile Exhibitions." Fashion Theory, vol. 12, no. 1, 2008, pp. 31-63.

Petrov, Julia. "cross-Purposes: Museum Display and Material Culture." Crosscurrents, vol. 62, no. 2, 2012, pp. 219-234.

Steele, Valerie. "Museum Quality: The Rise of the Fashion Exhibition." Fashion Theory, vol. 12 , no. 1,2008 , pp. 7-30.

Steele, Valerie. "A Museum of Fashion is More than a Clothes-Bag." Fashion Theory, vol. 2, no. 4, 1998, pp. 327-335.

Waugh, Norah. Corsets and Crinolines. Batsford, 1954. 